\title{
Role of debt-to-equity ratio in project investment valuation, assessing risk and return in capital markets
}

Vasishta Bhargava Nukala ${ }^{1 *} \mathbb{0}$ and S. S. Prasada Rao²

\begin{abstract}
In this paper, a case study was performed with an aim to analyze the asset returns for two different companies and the risk and returns from capital projects using standard capital asset pricing method. To demonstrate how the present values of future cash flows are influenced by discount rates when the debt-to-equity capital structure ratio is varied between 0 and 2.5 debt-to-equity. The breakeven sensitivity was also conducted in relation to different gross margin ratios of company. It was found that high value of debt-to-equity ratio yielded a flatter net present value with increase in gross margins. Capital appraisal techniques were applied to illustrate the project returns and annual cash flows and its relationship with change in cost of capital. Analysis showed that when average cost of capital is increased beyond threshold value, the net present value from the firm's project investments reduced significantly. A covariance analysis was performed to determine individual returns from two stocks traded in BSE Sensex and S\&P 500 indices using the beta values. Comparing the individual and total returns of two stocks revealed that returns not only increased with increasing beta values-but also varied with earnings potential, growth rate of firm, dividend payout ratios and trading stock price. The standard deviation on portfolio of two stocks has been computed for varying asset weight ratios. It has been found that positive correlation between two stocks increased equity risk when weight ratios are not balanced in portfolio, while a negative correlation reduced equity risk.
\end{abstract}

Keywords: Risk, Equity, Debt, Valuation, Earnings, Return

\section{Introduction}

For today's world of sustainable business operations, an insight of financial ratios provides useful information to predict company performance over long-run horizon. The economic growth and development of a nation depends on the efficient functioning of capital markets. In capital markets, equity and debt remain one of the important sources of external funding for an organization due to its low cost of borrowing power and flexible access, while depreciation and retained earnings are internal sources of funds. Retained earnings can be considered as form of equity which is associated

\footnotetext{
*Correspondence: vasishtab@gmail.com

${ }^{1}$ ICFAI University, Ranka Road, Lower Sichey Link Rd, Gangtok, Sikkim

737101, India

Full list of author information is available at the end of the article
}

with risk but vary significantly with firm's performance and external market conditions. Often equity valuation is a function of the maximum probable returns expected from a stock, risk-free rate of return prevalent in national economy as well as market risk premium. For stakeholders and financial managers, the financing mix of debt and equity instruments in a portfolio strongly determines the returns expected in long run [1]. Typically, returns from a capital project are profits or income derived from investments expressed as fraction of its cost. Financial analysts usually consider debtto-equity ratio as one of the important capital structure ratios for a firm's valuation. The extent of financial leverage is influenced by the debt-to-equity ratio, debt service and interest coverage as well as debt-to-asset ratio, among others. The introduction of Markowitz model laid one giant step in dealing with problem of 
portfolio selection by means of efficient combination of risky assets. It also emphasized pricing of securities and rational allocation of capital among different assets in portfolio to minimize risk and optimize returns [2]. The fundamental capital asset pricing model proposed by Sharpe [3], Lintner [4] and Black et al. [5] (SLB) is based on the portfolio theory proposed by Markowitz. The model predicts that average returns from a given stock are positive and linearly correlated with betas. However, this model has drawbacks in overestimating the pricing of individual or portfolio of stocks. It ignores the tax effect, transaction costs on securities in portfolio. Another weakness is that investors prefer the same level of returns for any combinations of assets in portfolio. In addition, investors can borrow without limits at risk-free rate of interest. Later, Fama and French by Fama and French [6] suggested that capital asset pricing model (CAPM) strongly correlates with fundamental analysis in which the firm size, volume of shares traded in market index, book-to-market ratio, i.e., book equity (BE) and market equity (ME), determine stock prices [7]. The sustainable growth of an organization depends on fundamental business model, its long-term goals and objectives framed by corporate governance committees. Most organizations which are in growth stage prefer to invest the long-term capital in profitable avenues which tend to complement their business model. However, few firms redistribute their earnings in the form of dividends to investors to drive the shareholder values and sustain long-term growth. Framing a dividend policy is one of most important decisions for a company to distribute excess cash to stockholders. In financial management, simplest model on dividend distribution was proposed by Gordon [8] and based on firm's growth rate which predicts the intrinsic value of stock based on periodic dividend payments to investors. Also, other complex dividend discount models such as Walters model are based not only on the intrinsic value of stock price, but also on equity capitalization rate and internal rate of return. The economic value of firm's assets is an strong determinant which not only enables the investors to estimate the intrinsic value of firm's stock price but also used by the financial analysts to discover the fair market value at which the stock can be sold or bought in open markets. Growth stock typically tends to have low BE/ME ratio with lower average returns, while value stocks have high $\mathrm{BE} / \mathrm{ME}$ ratios with higher average returns and are influenced by interest rate trends in the long run. The returns from either growth or value stocks depend on the market capitalization of firm. Value stocks usually represent the strongly established or matured companies which have higher book equity and trade at discounted prices in index while growth stocks trade at premium price and depend on the investor's preferences, time horizon, risk appetite and investment goals or objectives. The holding period return of stock is also essential in the valuation of stocks which can strongly affect the equity cash flows to investors [9]. Cash flows from short duration stocks may have better returns than the long-duration stock in a portfolio. Returns from portfolio of stocks to investors differ significantly and depend largely on the risk premium based on the capital asset pricing model. To a large extent, capital structure ratio is an important factor used in investment decisions in any organization or by a firm in specific industry. Among capital structure ratios, the debt-to-equity ratio strongly affects the firm's earnings in the long term. Depending on the financial leverage of a firm, capital structure ratios tend to have both positive and negative correlation with regard to the financial performance of a company. Adequate debt-to-equity ratio is essential to maximize the shareholders returns which impact the firm's stock price in the long run. According to technical analysis, the stock price returns rely on the historical values and often the required rate of return from a given stock tends to be volatile by very nature of uncertainty associated with market performance. In this paper, the capital asset pricing model is implemented as case study by assuming stock prices for two limited liability firms. The valuation of project investments for both companies is done taking account of internal rate of returns, net present values of cash flow generated from project operations. In addition, market risk and return assessment is done for two firms and compared to empirical financial data available in the Bombay stock exchange (BSE) Sensex and Standards and Poor (S\&P) 500 for period of two years, i.e., from January 2008 to December 2009. The regression analysis was performed by evaluating the covariance data for two stocks over a period of two years and comparing it with market index returns. This paper also attempts an application of price-to-earnings $(P / E)$ ratio to determine the returns from a stock under constant and variable earnings scenarios. Further, it correlates the capital structure ratios and its influence on long-run financial performance of firm under constant macroeconomic factor assumptions.

\section{Literature survey}

Chandra (2009) discusses about importance of debt-toequity ratio on the investment valuation methods involving capital projects, its planning, analysis, selection and review stages for small- and medium-scale enterprises. It also demonstrated that debt-to-equity ratio and cost of capital play a critical role in the profitability of projects. Also, an approach has been presented to evaluate 
several business scenarios and project returns using capital appraisal techniques taking account of internal rate of return (IRR), net present value (NPV) and discounted payback methods. The required rate of return is an important factor used by financial managers to determine the acceptance of project. Sometimes, a proxy to IRR can be assumed as cost of capital which represents the same as the weighted average cost of capital (WACC). In CAPM approach, the level of risk in a project investment varies according to the size of equity capital involved, discount rates and hence cash flows to project and external equity investors are not the same. This implies that minimum return required to compensate shareholders required rate of return on each project becomes cost of equity and depends on the extent of systematic risk. Riggs (1996) illustrated that the net present worth calculations of capital project investments from multinational organizations prefer debt financing methods utilizing high-yield low-risk bonds at low discount rates to maximize value to the stakeholders. To a large extent, the present value of series of cash flows tends to vary highly with discount rates and thus depend on macroeconomic factors.

Miller and Modigliani $[10,11](\mathrm{M}-\mathrm{M})$ proposed that investment decisions and dividend payout ratio do not affect the wealth of shareholders but are rather dependent on the earnings power of firm. Miller and Modigliani [11] specified that the fundamental principle of stock valuation is based on the fact that price of the share and total return, i.e., dividends and capital gains, on investments does not vary over long-time horizon. Further, it argues that even under perfect market conditions or zero uncertainty, it assumes that dividend policy remains irrelevant and does not affect the firm's stock prices in long run. So, a rational investor would prefer to sell the low-return high-price shares and buy low-price and high-return shares for benefit. Rational buying and selling of shares in organized markets tend to drive down the prices of low-return shares or drive up the prices of high return shares. Panda et al. [12] found that pecking order and agency cost theories which do not corroborate the capital investment decisions for the benefit of external stakeholders and firms management. Agency cost theory in contrast treats potential conflicts that arise between shareholders and business managers as an additional expense. This implies constraints on application of funds would cause inefficiencies in management or disruptions in business operations. In most manufacturing companies, higher debt financing is regarded as a preferred option since it is cheaper source of funds for finance managers. Van Horne and Dhamija [13] and Panda et al. 12 specify that pecking order theory relies on empirical evidence work and uses predominantly three sources of funds, viz. internal and external equity funds as well as retained earnings. According to them, the right mix of debt and equity is essential in corporate finance to ensure benefits overcome the costs for stakeholders. In corporate finance, a major source of asymmetric information occurs due to adverse selection of financial instruments or when information among shareholders, investors and management is exploited. Panda et al. 12 studied the case of 66 Indian steel manufacturing companies with mean debt-to-equity ratio of 2.12. A regression-based correlation technique was used to evaluate the profitability, growth and risk as independent variables. Van Horne and Dhamija [13] pointed out that for investment projects, finance managers often rely on senior debt and equity to finance projects due to the fact that senior debt can be obtained by a firm at low borrowing costs from financial institutions and prevent any agency costs associated with borrowing. Abdillah et al. [14] found that debt-toequity ratio of manufacturing companies are significantly affected the business risk for different financing scenarios. A cause-effect relationship was used in their research study to test hypotheses by applying statistical $\mathrm{F}$ test and partial $t$ test to predict the future share price movements and market value. Findings have shown that firm size and business risk tend to have positive effect when capital structure ratios are varied, while profitability has negative or inverse effect. Vacek et al. [15] studied project portfolio management using stochastic optimization model to develop strategic goal and benefits to small- and medium-scale business enterprises. For instance, portfolio returns were determined for a medium-scale pharmaceutical company that is privately owned in Czech Republic with sales revenue of 150 million CZK, total assets and liabilities of 150 million CZK. They found the management and board structure laid higher emphasis on the valuation of portfolio investments using discount cash flow methods taking account of correlation factors. D'Amico and De Blasis [16], Nageshwara and Prasada [17] have studied about the volatility in stock price using financial data available from US and Indian capital markets. They found that stock returns predicted using stochastic models obey normal distribution pattern and do not correlate well with real-time data. Results from the study have indicated that actual stock prices are difficult to predict using multivariate Markov chain and stochastic optimization models as they do not give qualitative information to rational investors. This study aims to correlate the production revenue, financing costs and investment requirements by assuming different debt-to-equity capital structure ratios. A sensitivity study has been conducted to assess the effect of discount rates on the net present values of firm's assets. The impact of internal rate of return on the cash flows to investors are discussed, and 
the returns at different average cost of capital are illustrated. Financial data available from S\&P500 and BSE Sensex indices are utilized to compare the two-year market index returns with individual stock returns for two firms.

\section{Assumptions and objectives of study Assumptions}

Financial variables for the project investments for a company AVS Ltd are

- Initial investment worth Rs 50 million in year 0

- Depreciable fixed assets worth Rs 30 million; depreciation per written down value method, on equipment depreciated toward 25 years. Depreciation rate scheduled at $13 \%$ annually.

- Capital expenditure worth Rs 50 million.

- Financing mix: debt and equity; no preferred capital.

- Corporate tax rate at $30 \%$

- Debt financing summary

a. Nonconvertible debentures (NCD), term loans, commercial paper

b. Interest rate on working capital is $12 \%$, while for term loan is $14 \%$

c. Coupon rates fixed at $10 \%$, for period of 25 years.

d. Face value of bond is Rs 1000 .

e. Bond yield at 5.6\%. Typically, values are decided based on the risk-free rates of long-term government treasury bonds. Credit rating: The bonds are assumed to belong to moderate risk with investment grade, BBB-CRISIL and LBBB-ICRA rating.

Figure 1 shows a convex or inverse relation between the bond price and bond yield curves relative to maturity period. It implies that as the coupon payments decrease, the running yield would increase over bond life. Also, as the bond price is reduced, the yield-to-maturity (YTM) is increased, ceteris paribus. However, in practice bond YTM considers external macroeconomic factors which include inflation premium and detailed analysis for change in bond prices are beyond the scope of the present study. Typically, a corporate bond's face value is retired in the form of bullet payment toward its maturity period, while a bond's price is calculated using the sum of the present values of all future coupon payments and present value of face or par value at its maturity. As stated before, bond yield can be estimated based on the internal rate of return of cash flow payments of a bond for any given period. On the other hand, bond price may fluctuate with market interest rates that could affect the bond value during its life. This also means an investor would be able to make better investment decision based on the prevailing market rates and by considering the changes to bonds credit risk rating.

\section{Objectives}

- To evaluate the risk and return from the stocks using the capital asset pricing method. Compare risk and

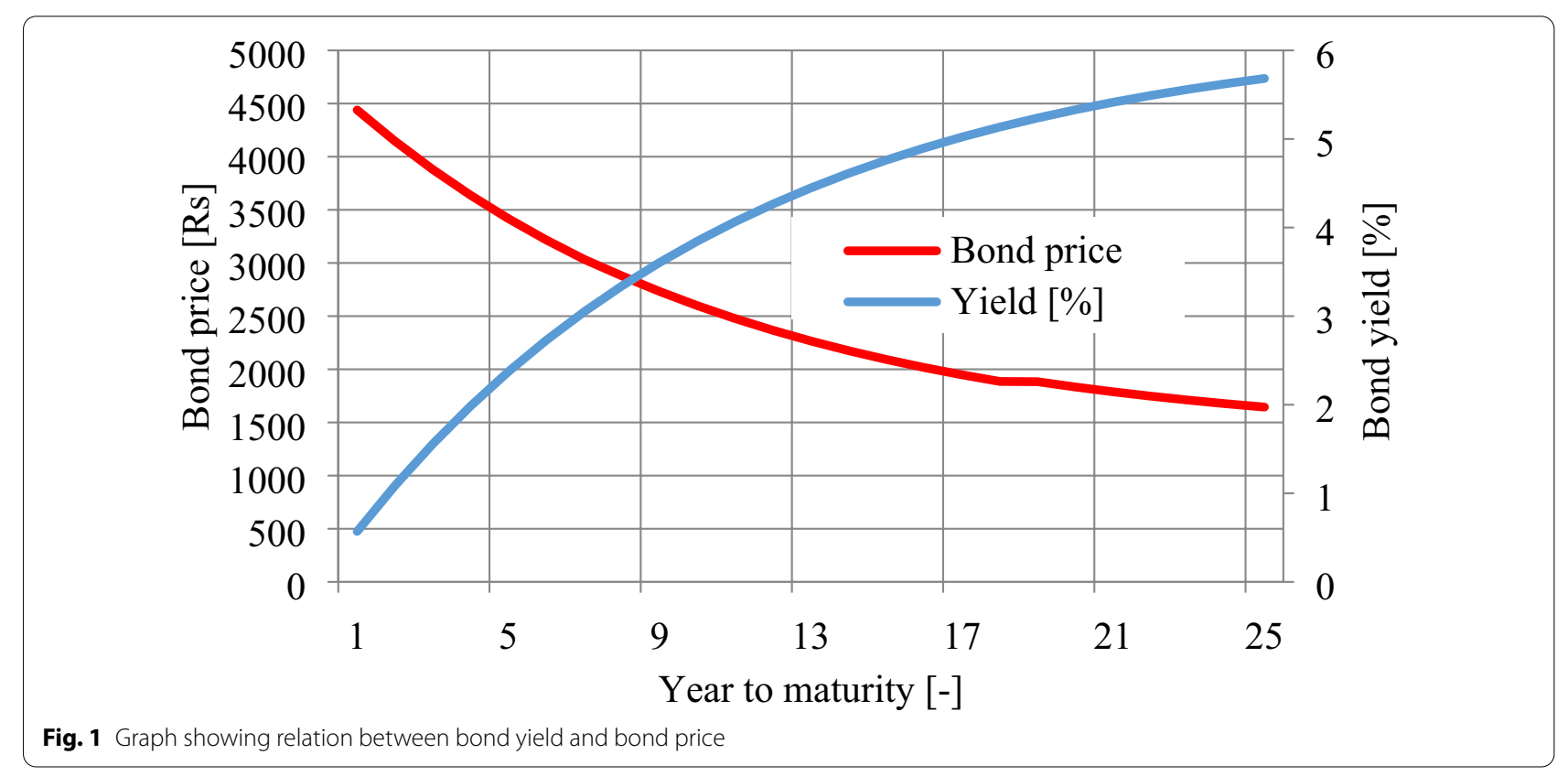


return from individual stocks for two firms with the benchmark or index returns.

- Compute the returns from the stock trading in US and Indian capital market and perform the valuation using the comparable method utilizing the earnings per share and current market price of share.

- Prepare payment schedule for the firm's asset that takes account of written down and diminishing balance methods of depreciation.

- Perform the sensitivity analysis of present value of cash flows with respect to the weighted average cost of capital and determine the breakeven gross margin percentage as a function of cost of capital for different debt-to-equity ratios.

\section{Methods}

\section{Revenue function and cost function}

In this section we assume, a hypothetical company, AVS Ltd, which is involved registered hypothetical company AVS Ltd is involved in the production of ancillary automobile components in the industry. The revenue function is defined according to the empirical Eq. (1)

$$
K=1.1 \sqrt{n}
$$

where $n$ is number of units produced by the machinery equipment and sold per year, $K$ is the sales revenue in millions per year. From Eq. (1), the revenue function varies nonlinearly with the annual production quantity. This quantity is strongly correlated with annual demand for the product. Most manufacturing firms consider forecasting of demand as critical factor to predict the annual sales revenue and the implicit costs associated with product sales. The cost function for the plant is defined according to Eq. (2)

$$
C=10 \cdot 2.5^{\left(\frac{1}{n}\right)}
$$

The constants in both revenue and cost functions are obtained by correlating the long-term annual product sales with production output. Figure 2 shows the total revenue and cost for the useful economic life of the asset which is engaged in the business of making ancillary automobile components. It is apparent that cost function also varies according to annual number of units produced by a firm. The annual sales revenue and cost function are thus related to production quantity. As stated, earlier information pertaining to demand is a key indicator of number of customers and prognostic revenue for a firm. In the present study, both revenue and cost functions of the company are assumed as empirical estimates that are correlated with the annual production outputs.

Figure 3 shows the depreciation value of property or plant capital equipment over its useful economic life for which no replacement value of asset is considered. So, depreciation value of plant and equipment varies according to depreciation method adopted by a firm. Further depreciation charges may depend upon the condition and nature of asset in long-run operation. The market value of capital asset at the time of acquisition and its scrap value at end of its economic life are other strong determinants which affect the depreciation value of equipment. So, it can be said that the operating costs of assets continue to rise despite that income from an asset is assured. In the present study, written down value and reducing balance methods have been implemented to compare the changes to the value of depreciation charges each year. However, in corporate finance, decisions made by financial managers with regard to valuation of an asset provide critical information for the long-term estimates of depreciation values. In estimating depreciation values, written down value method is preferred since it takes into account both depreciation and book values, i.e., bought price, as reference. Further, the charges determined also depend on the scrap value and useful economic life of asset. A change in one method of depreciation to another is made often only if the adoption of new method is required by statutory body or compliance with accounting standards. Firms also tend to adopt this method when appropriate

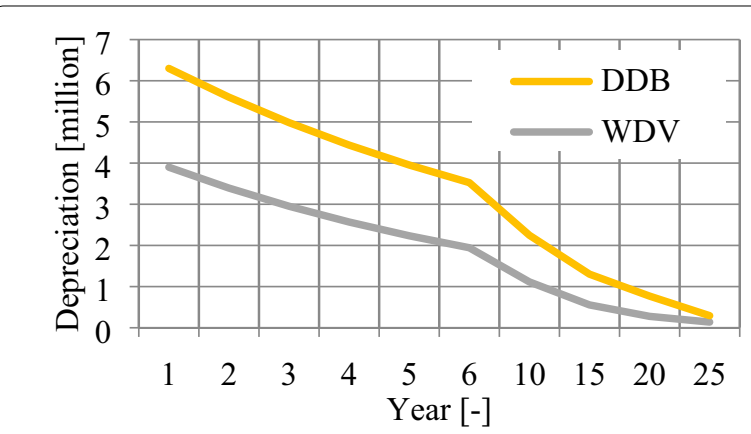

Fig. 3 Illustration of depreciation methods
Fig. 2 Total cost, operating cost and revenues (million) for AVS Ltd

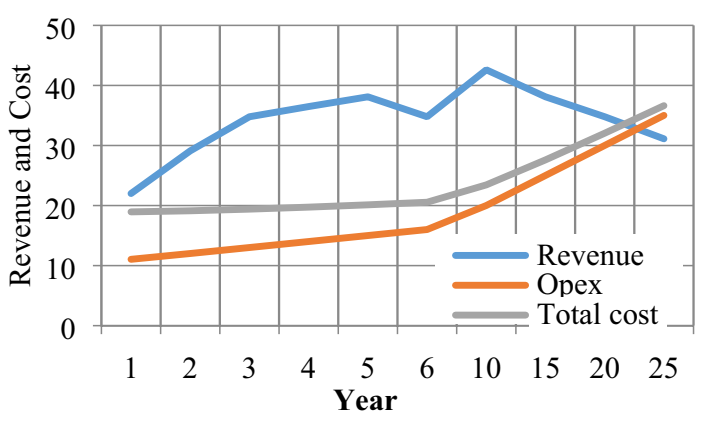

. 2 Total cost, operating cost and revenues (million) for AVS Ltd 
presentation of financial statements is required. Financial statements do not necessarily reflect the market value of an asset in practice. However, they do provide enough information for financial analysts and investment managers to conduct the fundamental analysis to predict future financial performance of individual firms. Here, a comparison between the written down value and double declining balance (DDB) is shown which allows the analyst to assess the difference on charges and its effect on the operating cash flows during valuation [18]. Further in Fig. 4, the debt payment schedule for such a company is compared with interest payment terms. It involved Rs 30 million containing Rs 20 million of term loans and Rs 10 million of working capital advances from bank to the firm. The interest rates for working capital and term loans are $12 \%$ and $14 \%$, respectively. One can notice that principal outstanding is completed in the 20th year of operation. It can be noted that the interest payments shown for the term loans are added cumulatively and completed by end of asset life according to the assumptions listed in "Assumptions" section. However, in practical cases, interest payments due to working capital could continue due to fact that firms tend to use revolving credit facility for sustaining long-run business operations. It can be noted that interest rate can vary each year according to the credit lending terms agreed between the firm and financial institutions. Thus, a straight line does not indicate the equal annual payments for the working capital.

\section{Net cash flows and changes to debt-to-equity capital structure ratio}

In this section, the annual cash flows to the equity investors are computed that takes account of long-term debt. The overall or total cash flows to equity and debt investors in the company are compared. For simplicity purposes, the interest rate on working capital finance obtained from the banks, term loans from banks are kept constant throughout the useful economic life of asset. The depreciation charges of assets and the scrap value of assets also serve as source of funds to an organization and hence are added back to derive the total cash flows. The total cash flows are calculated utilizing the initial, operating and end cash flows, respectively (Martin and Anshuman 2009). Cash flows depending on economic situation can turn positive or negative. To evaluate investments, finance managers use project hurdle rates (IRR) with different levels of risk. The higher discount rates imply offset in optimistic cash flow forecasts. Figure 5 shows the annual cash flows to the equity and debt investors in the operating life of the asset. It can be noted that as the operation and maintenance cost of the asset increases, the cash flows to the equity investors become lower than to debt investors. However, this trend may vary according to nature of asset or cost of ownership by a firm.

The scrap values for fixed and current assets are Rs 5 and Rs 10 million. The net present values for assets are evaluated using the three different cases of debt-to-equity ratios. It can be noted that the IRR from investment side implies that a lower cost of capital for project is preferred for investors since it provides higher returns and positive

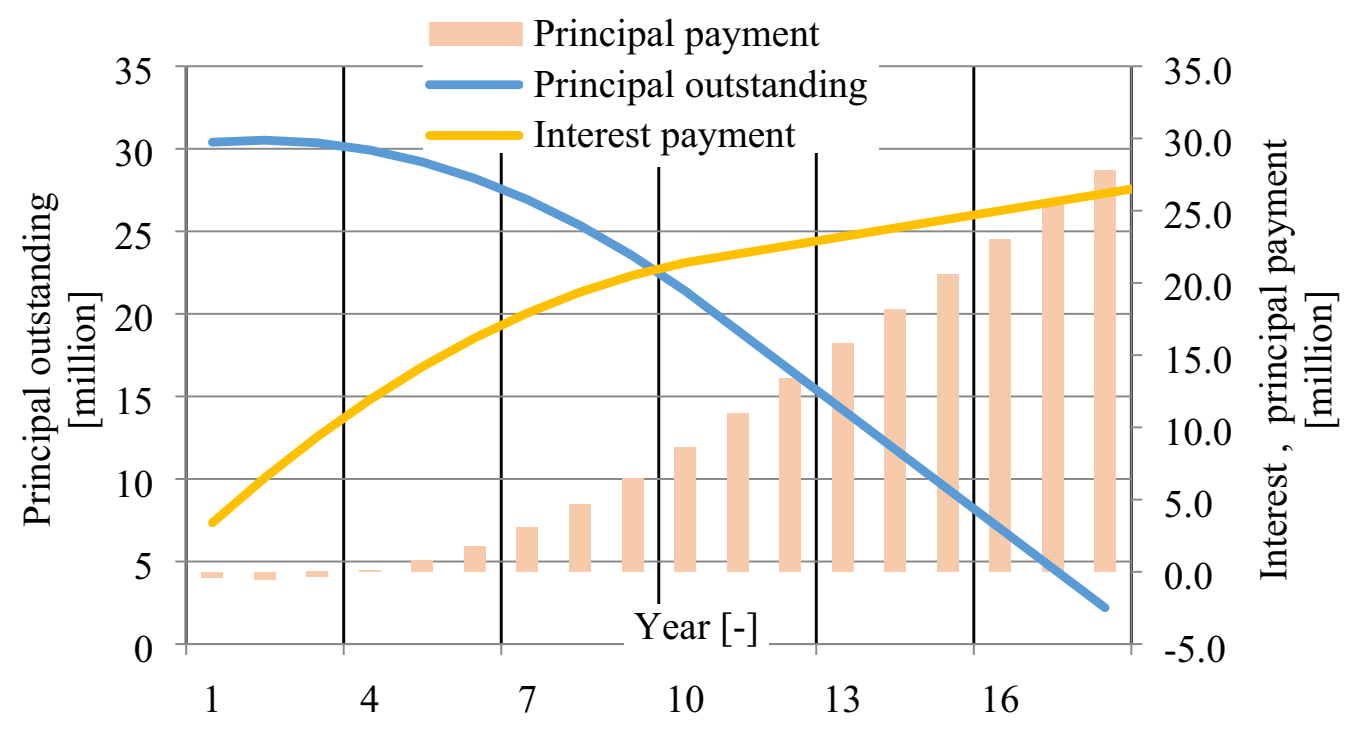

Fig. 4 Payment of debt (principal + interest) over the life cycle of asset 


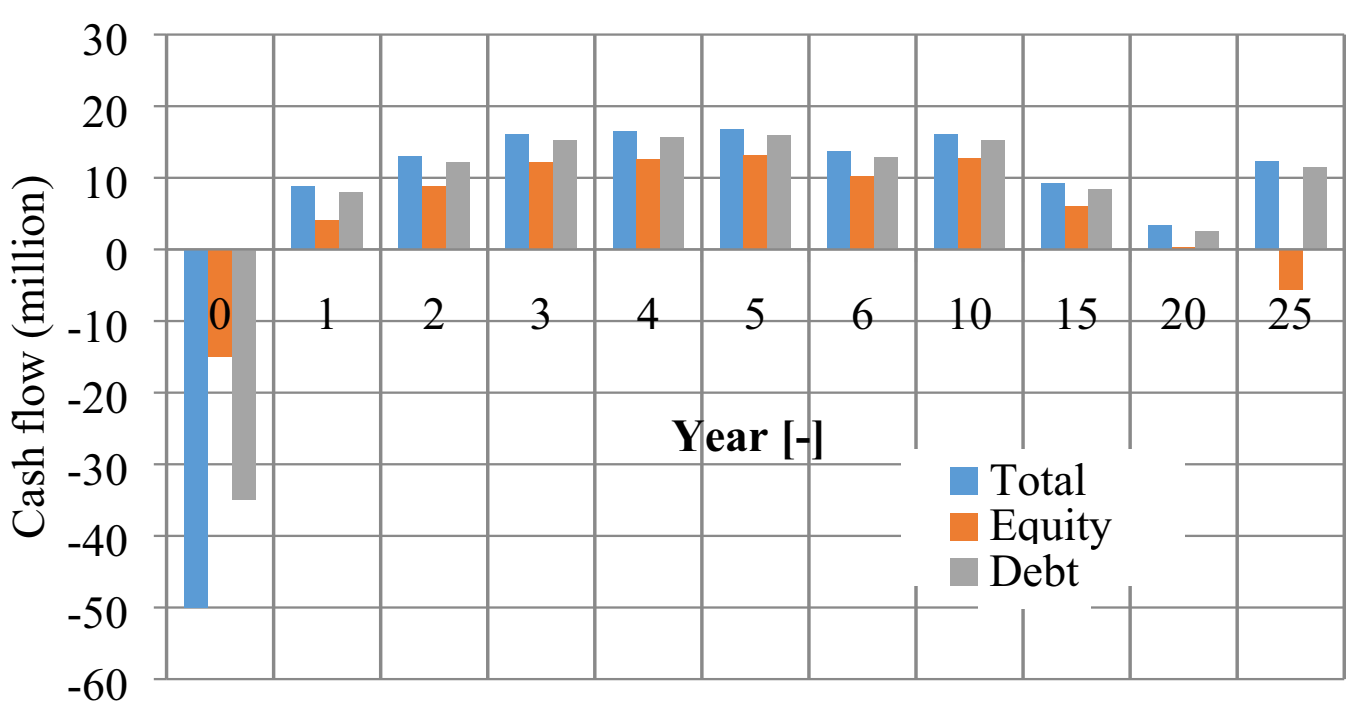

Fig. 5 Annual cash flows to investors

net present value at WACC values less than $12 \%$ for the project. The weighted average cost of capital is calculated using Eq. (3)

$$
\mathrm{WACC}=C_{E} P_{E}+C_{D} P_{D}+C_{D} \cdot(1-T) P_{D}
$$

where $C_{E} C_{D}(1-T)$ is the cost of equity and debt, $P_{E}$ $P_{D}$ are proportions of equity and debt, $T$ is corporate tax rate, respectively [19]. In the present study, no preferential capital is issued to investors; hence, its cost and proportion are zero. The proportions or weights frequently

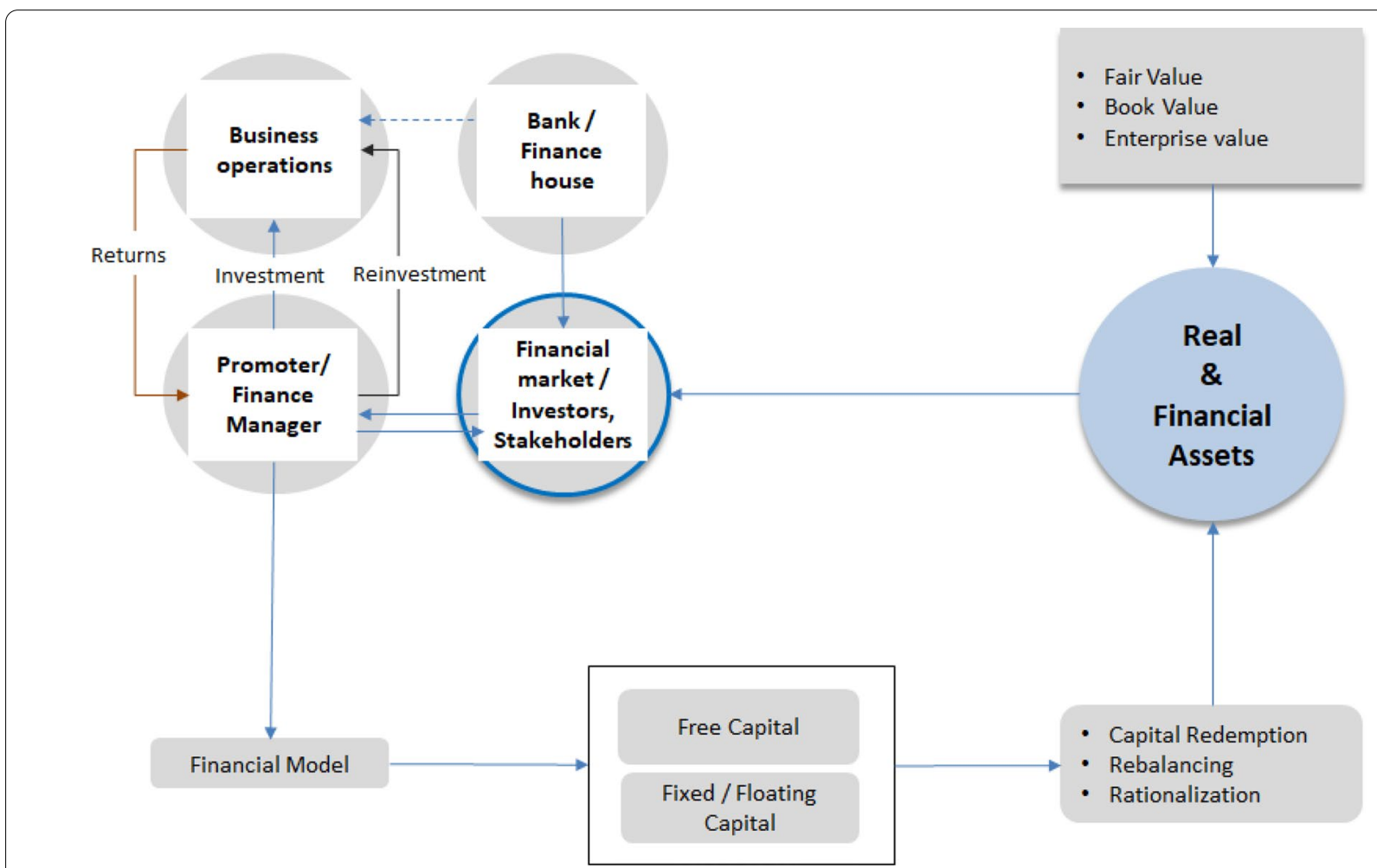

Fig. 6 Illustration of the relationship among the financial entities and processes in corporate finance 
use the book value as the reference rather than market value from historic survey in industry.

From Fig. 6, it can be noted that relationship between top management of a company with investors, stakeholders would impact stock price value for a company based on the financial model or policy framed for longterm horizon. The free capital accrued in a firm's treasury could be either distributed to shareholders in the form of dividends or reinvestment back to existing business operations or in expansion projects. In addition, free capital can be used for strategic acquisition of other businesses. For such cases, optimal financial leverage allows the managers to allocate resources in such a way to minimize conflict between investors, shareholders and firm's management. In the context of long-run financial performance, asset reallocation is a complex and important step adopted by financial managers to determine the favorable long-run return on asset ratio. It can be said that asset reallocation and rebalancing act as strategic growth driver to ensure high returns to investors of and therefore, return on asset ratio is not dealt in detail in present study. Also, organization follows steps so that the fixed capital and floating capital are reallocated in a more efficient manner. This is often done to ensure the growth and profitability by increasing the return on asset ratio and other capital structure ratios [20]

Figure 7 describes about the relation among capital market entities and shows how reduction of capital affect the earnings yield and earnings per share values. Capital reduction is done when management wants to reduce liability. The reduction in liability has net positive effect on share price which tend to maximize shareholders value. Another important reason for capital reduction occurs when the issued share capital does not match with the fair value of assets or when asset impairment happens significantly faster in the short run business operations.

\section{Steps involved in calculating weighted average cost of capital (WACC)}

1. Identify components in capital structure mix.

2. Prepare a possible estimate of opportunity cost for sources of finance.

3. Finally, calculate the weighted average cost of capital

Figure 8 shows the trends for net present values with weighted cost of capital for three different debtto-equity ratios. The internal rates of return are $11 \%$,

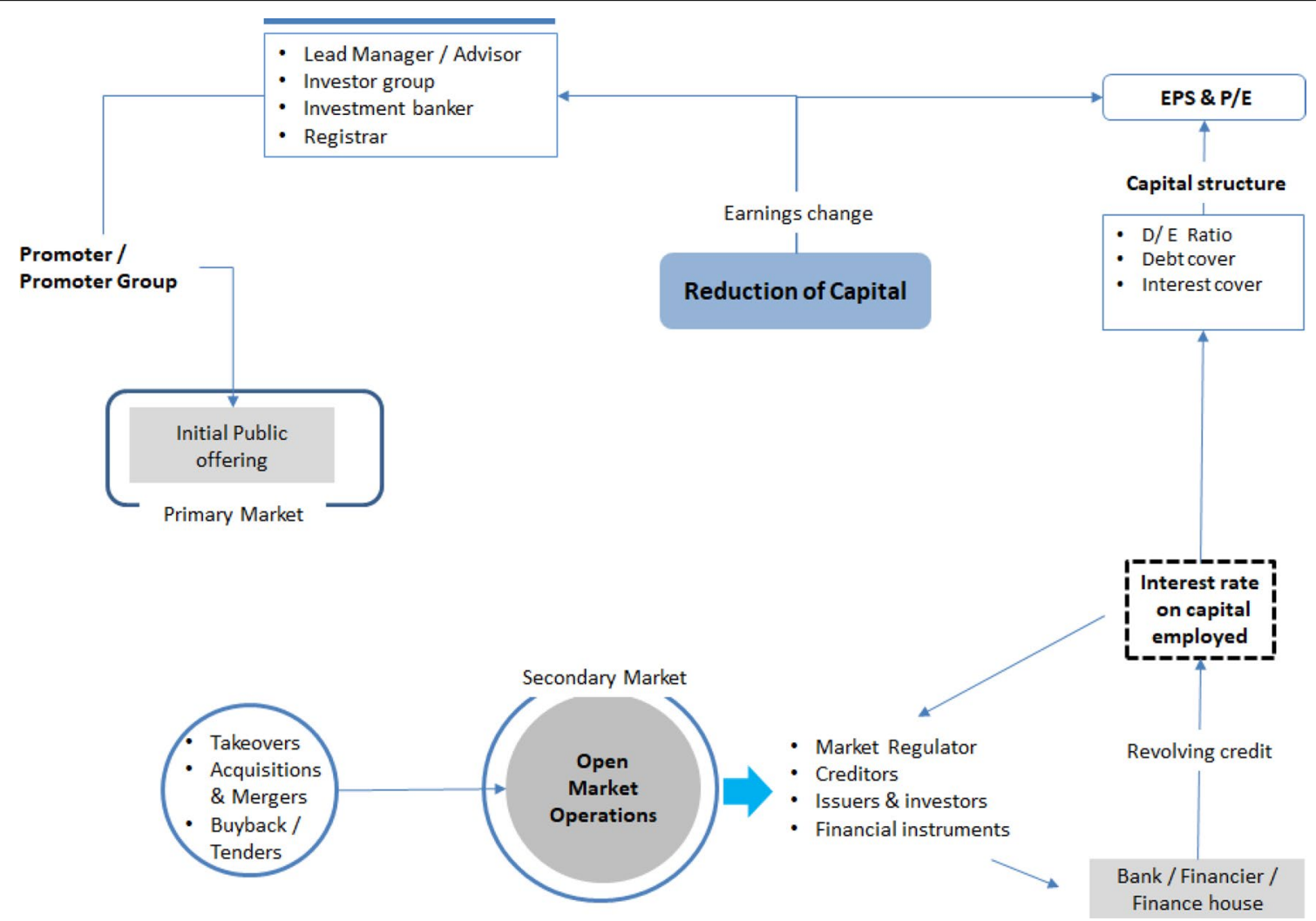

Fig. 7 Diagram showing relationship among capital market entities and capital structure ratios on the earnings yield and earnings per share 


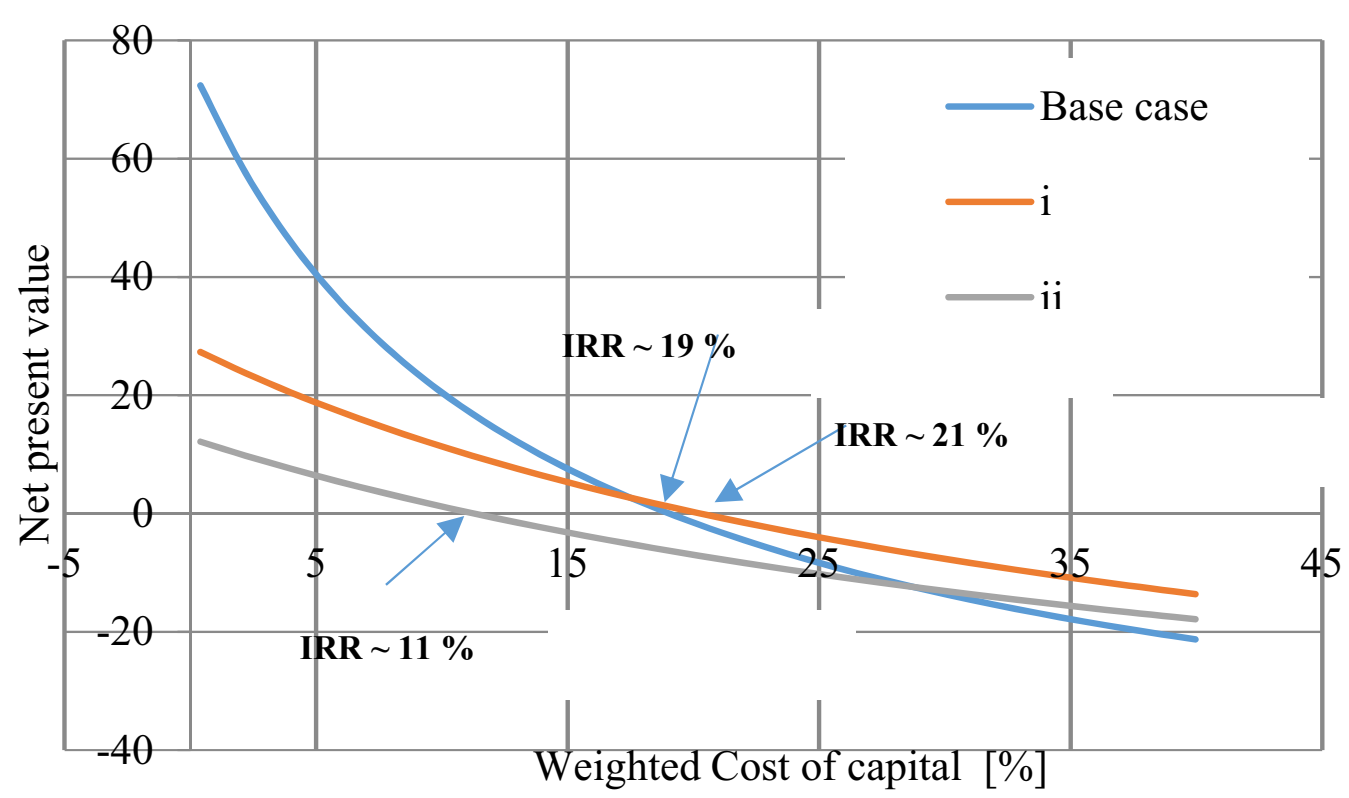

Fig. 8 Illustration of net present values (million) for three different debt-to-equity ratios

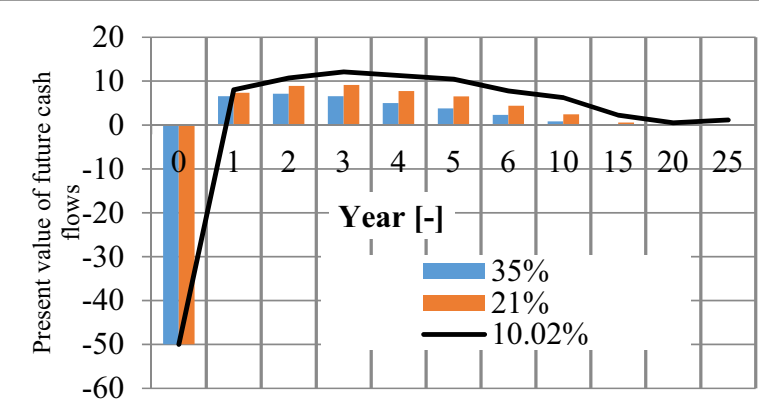

Fig. 9 Net present values (million) of series of cash flows for different weighted costs of capital

$19 \%$ and $21 \%$ for three cases considered when the net present values of the assets become zero. This demonstrates that for a given debt-to-equity ratio, a lower value for IRR is considered unfavorable by finance managers. So, a project approval is done only when the required rate of return is higher than the cost of capital. Further, case ii produces favorable returns for the project which is offset by higher cost of capital. Management therefore may prefer to take investment and financing decision based on projects whose internal rate of return far exceeds the cost of capital.

The cost of debt therefore depends strongly on several parameters for instance, the yield to maturity or discount rate considered, coupon rate on bond face value and the maturity period of the bond. Since the value of debt capital changes according to the discount rate or the market rate of interest, a comparison has been made to illustrate the effect of discount rate on the net present value of asset. From Fig. 9, it can be noted that present values of future cash flows from the assets are negative at the beginning when the capital is borrowed. At the end of first year of operation, the cash flows are seen to increase up to 12 million when the inflows exceed outflows for the project. This increasing trend is observed up to fifth year of operation. One can notice that cash flows are higher when the cost of capital is lowest, i.e., $10.02 \%$ and vice versa. This trend is also similar for remaining two costs of capital, i.e., $35 \%$ and $21 \%$, respectively. The impact of three different weighted average cost of capital on the present values shows that as the cost of capital is increased, the difference in present values of cash flows varied by $~ 10 \%$ except for the first year of operation.

\section{Net profits after taxes}

In this section, the net operating income for a firm is evaluated for three financial scenarios to understand the importance of leverage on cash flows and earnings of company. The base case scenario has $\mathrm{D} / \mathrm{E}$ ratio of 2.33 , while case $i$ has $\mathrm{D} / \mathrm{E}$ ratio of 1.5 , and case $i i$ has $\mathrm{D} / \mathrm{E}$ ratio of 1 . The initial total investment is $\sim$ Rs 50 million, fixed and current assets for organization. The case $i i$ is considered with $99 \%$-debt capital as trade credit on which there is no interest. The average rate of return (ARR) for such case ii is higher compared to base case 
Table 1 Illustration of after-tax profits (million) using ARR and payback methods

\begin{tabular}{|c|c|c|c|c|c|c|c|c|c|c|c|c|}
\hline & \multicolumn{10}{|c|}{ Year } & \multirow{2}{*}{$\begin{array}{l}\text { ARR } \\
\%\end{array}$} & \multirow[t]{2}{*}{ Payback (yr } \\
\hline & 1 & 2 & 3 & 4 & 5 & 6 & 10 & 15 & 20 & 25 & & \\
\hline Base case & 2.1 & 7.0 & 10.8 & 11.7 & 12.6 & 10.0 & 13.4 & 7.4 & 1.9 & -3.9 & 14.5 & 5 \\
\hline Case i & 4.9 & 7.7 & 11.5 & 12.5 & 13.3 & 10.7 & 14.2 & 8.1 & 2.7 & -3.1 & 15 & 5.58 \\
\hline Case ii & 3.7 & 6.6 & 10.3 & 11.3 & 12.2 & 9.5 & 13.0 & 6.9 & 1.5 & -4.3 & 16.2 & 5.61 \\
\hline
\end{tabular}

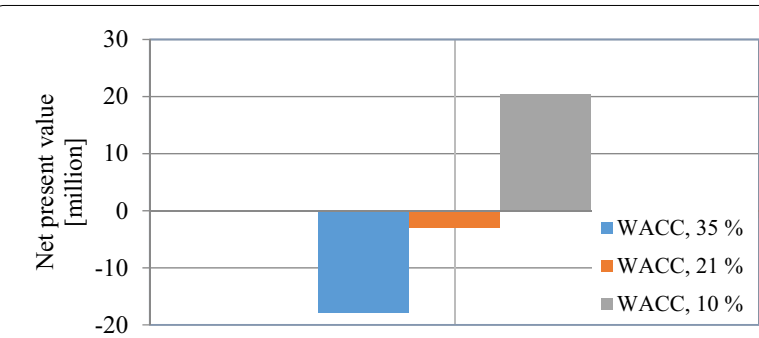

Fig. 10 Comparison of net present values for project at different weighted average costs of capital

and case $i$ respectively. Table 1 shows the profits after taxes base case of $\mathrm{D} / \mathrm{E}$ ratio and when the $\mathrm{D} / \mathrm{E}$ ratios are 1.5 and 1 , respectively. For $\mathrm{D} / \mathrm{E}$ ratio of 1.5 (case $\mathrm{i}$ ), the average rate of return continued to increase to $15 \%$, while the payback on project differed by approximately six months compared to the base case. Similarly, when the $\mathrm{D} / \mathrm{E}$ ratio is 1 (case ii), the average rate of return is $\sim 16.2 \%$ with payback duration of about five years and seven months. This shows that $\mathrm{D} / \mathrm{E}$ ratio has positive effect on average rate of return. In contrast, the simple payback method shows a negative or inverse effect when the $\mathrm{D} / \mathrm{E}$ ratio is reduced. This difference implies that simple payback method does not take account of time value of money when evaluating net income and hence shows negligible difference for all three cases of $\mathrm{D} / \mathrm{E}$ ratios.

Both payback and average rate of return methods are good measures of liquidity only and ignore time value of money. Further, the average rate of return does not take account of timing of cash flows and a cutoff rate of return fixed by management usually signifies whether the project can be accepted or rejected. Similarly, payback method does not ensure the magnitude of cash flows for a specified time duration; it accounts only for recovery duration as whole and hence a drawback. In the present study, payback and ARR were chosen to determine net income because they are simpler to evaluate compared to IRR and NPV methods which rely on more complex discount rates calculation.

In Fig. 10, the net present values of project for three different weighted average costs of capital are

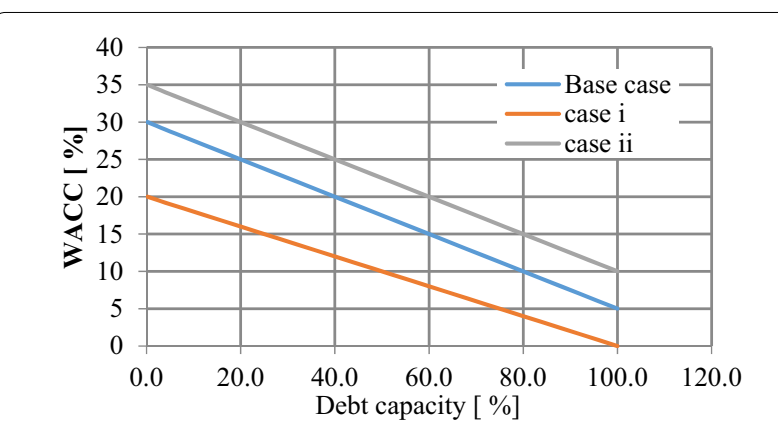

Fig. 11 Illustration of WACC with changing debt capacity for three different debt-to-equity ratios

demonstrated. These values are obtained when cost of debt is kept fixed rate over the entire life of asset; however, in most practical scenarios, cost of lending debt funds to firms and returns from debt investments are not constant and vary with prevailing interest rates in national economy. The net present values of future cash flows for three different cases of weighted average cost of capital of $10 \%, 21 \%$ and $35 \%$ are Rs 21 , -0.33 and -19 million, respectively. It must be noted that net present values and internal rate of return in all scenarios are evaluated according to Eq. (8.3) and Eq. (8.6) given in reference Van Horne and Dhamija [13]. Figure 11 demonstrates that as the debt-to-equity ratio decreases, the slope of the line for the weighted average cost of capital continues to decrease with increase in the debt capacity. As the debt capacity - is increased, the cost of capital decreases until it reaches zero for $100 \%$ debt capacity. A low debt capacity or leverage implies that firm relies on increasing equity capital for business operations. The three cases illustrated in Fig. 11 represent different weights for equity and debt that make up the capital structure ratio. Further, it can be noted for some cases the risk of investment in this is never completely zero when suitable proportions of debt and equity capital are chosen. Also, from Fig. 10, the net present value is Rs 21 million when the WACC is $\sim 10 \%$, while NPV is negative for when WACC values are $21 \%$ and $35 \%-$ Hence, all 


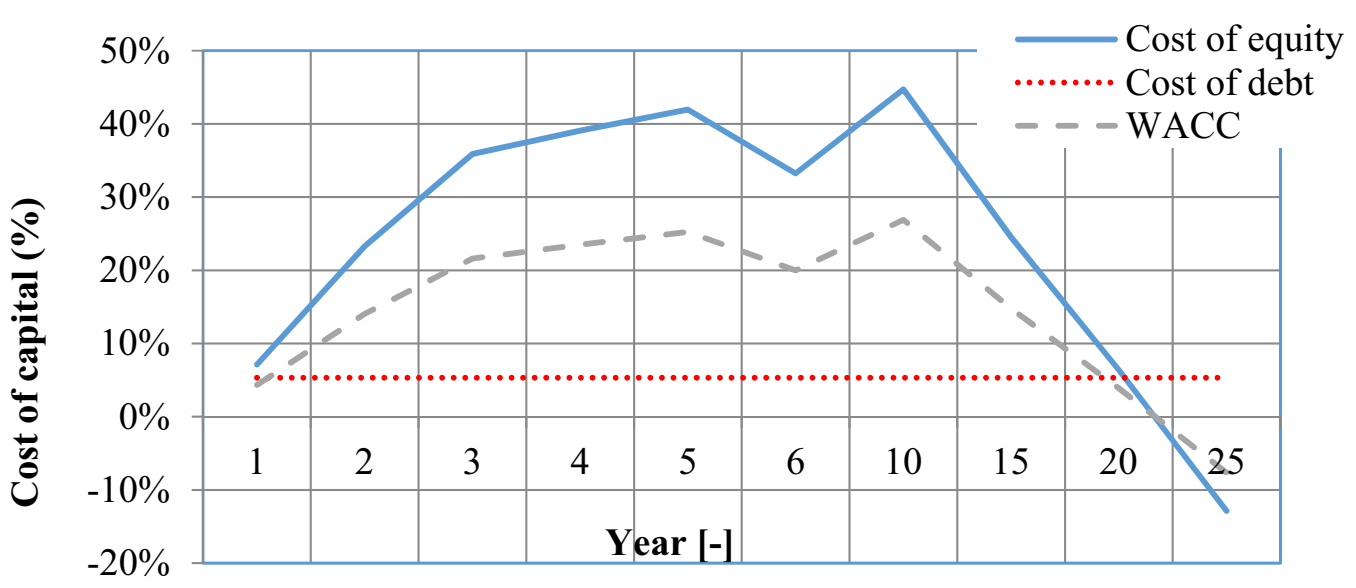

Fig. 12 Comparison of equity and debt cost of capital with weighted average cost of capital

projects that satisfy a WACC of $10 \%$ or less are recommended and acceptable.

Figure 12 shows the change in the cost of capital during the long-run asset operations of the firm. Evidently, the cost of debt capital remains constant in long run, while the weighted average cost of capital is driven by cost of equity. The market price of stock and returns derived from portfolio, along with investor attitude toward risk ascertain the performance of stock in the industry and in financial markets. So here, it is adequate for a company involved in the production of ancillary automobile parts to compare its equity returns with its peers in the industry.
Figure 13 shows the breakeven sensitivity analysis for two different debt-to-equity ratios. Further, gross margins are closely spaced when the debt-to-equity ratios are not significantly different. Hence, with the increase in the gross margin percentage, the net present values tend to increase with higher values for debt-to-equity ratio.

\section{Results and discussion}

In this section, risk and return are evaluated using capital asset pricing method for two stocks $A$ and $B$ trading in BSE Sensex and S\&P market index. Covariance analysis has been conducted on stock data for portfolio of

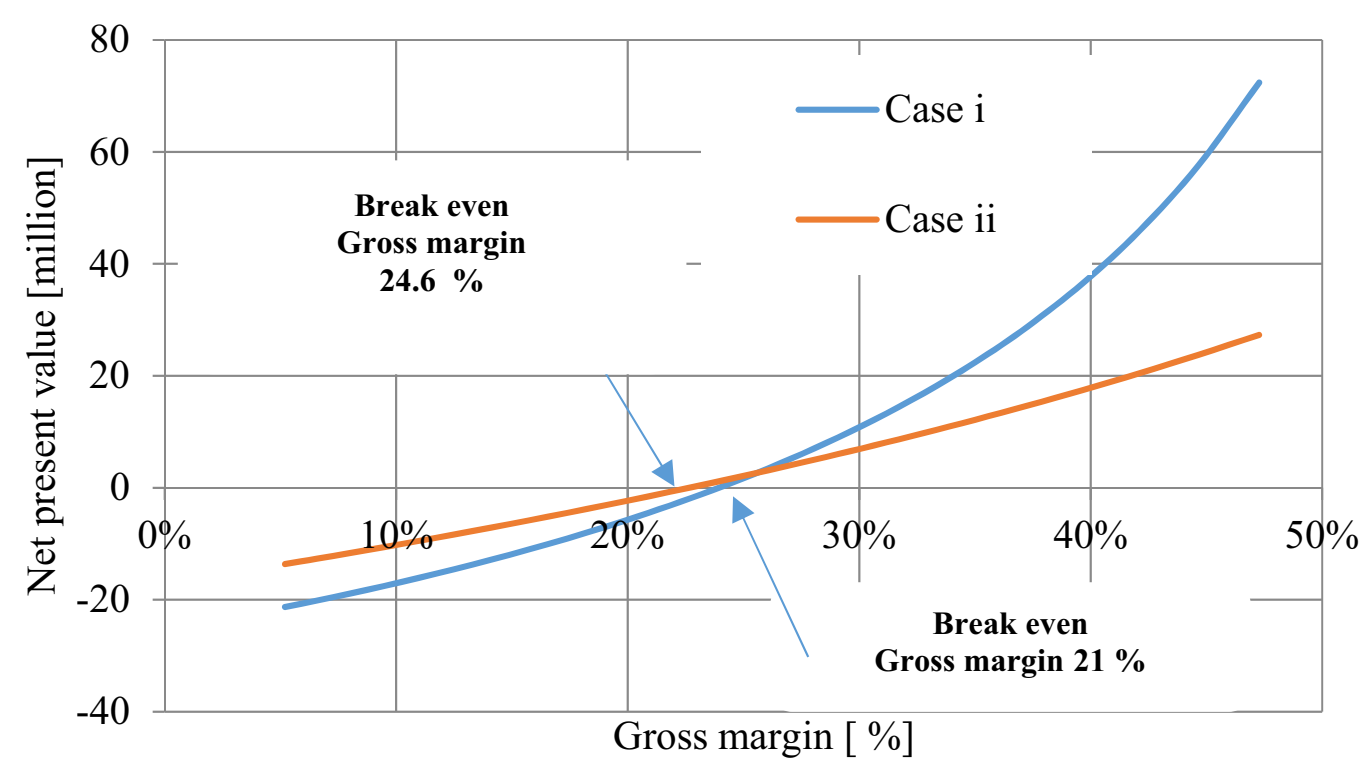

Fig. 13 Illustration of breakeven sensitivity analysis for two different debt-to-equity capital structure ratios 
two stocks, and expected rates of returns for a period of 2 years are compared. Beta values for two stocks are computed to assess the required rate of returns in both market indices. Gordon growth and Walters dividend models have been applied on stock data to analyze the effect of dividend payout on the stock returns. Total returns on stock are also evaluated based on the stock price information obtained from market indices. Finally, influence of $P / E$ ratio on stock returns has been evaluated.

\section{The CAPM approach}

As mentioned earlier, the capital asset pricing model is a single-factor equilibrium model which relates the expected rate of return with stock beta. Beta is often a measure of risk sensitivity of stock price relative to market return and obtained statistically by dividing the covariance of stock return with market return and variance of market return. Risk-free rate of return is defined as return derived from investment at which risk is essentially zero. Risk premium can be obtained using the difference between the market rate of return and the risk-free rate for a given time horizon [13]. It must be noted that beta here refers to standard beta which means the capital structure of the company is reflected in terms of both debt and equity components only. For the present study, the risk-free rate is assumed as $\sim 5.01 \%$ and $6 \%$ for stocks $A$ and $B$ trading in BSE Sensex, while it is assumed as $6.62 \%$ and $7.34 \%$ trading in S\&P 500 indices. The common reference to this value is usually the rate of return from the short-term government or treasury bonds and considered least controversial. The data for the monthly average closing market price and the stock price for the companies over the period of two years are used for the study. Next covariance for two stocks $A$ and $B$ and deviation with respect to market return are demonstrated in Table 2.

\section{Illustration of calculations}

For the expected return from the stock, the market risk premium is required to be calculated after the estimation of stock beta and then added to the risk-free rate of return. Market risk premium, on the other hand, changes

Table 2 Covariance calculation for stocks $A$ and $B$ with respect to market return

\begin{tabular}{|c|c|c|c|c|c|c|c|}
\hline \multirow[t]{2}{*}{ Month no } & Stock return (\%) & Stock return (\%) & Market return (\%) & $\begin{array}{l}\text { Deviation of } \\
\text { market return } \\
\text { from its mean }\end{array}$ & $\begin{array}{l}\text { Square of } \\
\text { deviation }\end{array}$ & $\begin{array}{l}\text { Product of } \\
\text { deviation A }\end{array}$ & $\begin{array}{l}\text { Product of } \\
\text { deviation B }\end{array}$ \\
\hline & $A_{R}$ & $B_{R}$ & $M_{R}$ & $M_{\mathrm{R}}-M_{\mathrm{avg}}$ & $\left(M_{R}-M_{\mathrm{avg}}\right)^{2}$ & $\begin{array}{l}\left(A_{R}-A_{\text {R,avg }}\right) \times \\
\left(M_{R}-M_{\text {Ravg }}\right)\end{array}$ & $\begin{array}{l}\left(B_{R}-B_{\text {R,avg }}\right) \times \\
\left(M_{R}-M_{\text {Ravg }}\right)\end{array}$ \\
\hline 1 & -1.71 & 1.53 & -0.86 & -0.18 & 0.03 & 0.53 & -1.47 \\
\hline 2 & 10.10 & -4.10 & -6.45 & -5.77 & 33.34 & -50.96 & -15.18 \\
\hline 3 & 0.59 & -20.73 & -5.97 & -5.29 & 28.00 & 3.58 & 74.11 \\
\hline 4 & 9.09 & 8.33 & 9.50 & 10.18 & 103.70 & 79.67 & 153.36 \\
\hline 5 & -4.95 & -20.05 & -5.31 & -4.63 & 21.44 & 28.81 & 61.69 \\
\hline 6 & -13.09 & -48.27 & -21.94 & -21.26 & 452.14 & 305.43 & 883.32 \\
\hline 7 & 16.30 & 22.19 & 6.23 & 6.91 & 47.73 & 103.85 & 199.80 \\
\hline 8 & 2.38 & -3.24 & 1.43 & 2.11 & 4.467 & 2.34 & 7.37 \\
\hline 9 & 2.51 & -39.56 & -13.25 & -12.57 & 158.02 & -15.52 & 412.68 \\
\hline 10 & -11.95 & -60.49 & -31.39 & -30.71 & 943.03 & 405.88 & 1650.94 \\
\hline 11 & 6.64 & -11.07 & -7.65 & -6.97 & 48.54 & -37.38 & 30.25 \\
\hline 12 & 5.95 & 29.67 & 5.75 & 6.43 & 41.33 & 30.07 & 234.03 \\
\hline 13 & 4.38 & -59.09 & -2.37 & -1.69 & 2.85 & -5.24 & 88.32 \\
\hline 14 & -2.83 & -16.81 & -5.99 & -5.31 & 28.20 & 21.79 & 53.53 \\
\hline 15 & -6.15 & 9.27 & 8.41 & 9.09 & 82.71 & -67.46 & 145.51 \\
\hline 16 & -1.53 & 27.59 & 14.86 & 15.54 & 241.56 & -43.57 & 533.36 \\
\hline 17 & -1.47 & 42.75 & 22.03 & 22.71 & 515.77 & -62.28 & 1123.64 \\
\hline 18 & 15.58 & -29.76 & -0.91 & -0.23 & 0.05 & -3.24 & 5.22 \\
\hline 19 & 9.02 & 21.55 & 1.87 & 2.55 & 6.51 & 19.78 & 72.16 \\
\hline 20 & -10.77 & 6.61 & 5.72 & 6.40 & 40.98 & -77.05 & 85.39 \\
\hline 21 & 1.15 & 3.15 & 8.53 & 9.21 & 84.75 & -1.07 & 90.96 \\
\hline 22 & 7.65 & -18.38 & -7.74 & -7.06 & 49.86 & -45.02 & 82.25 \\
\hline 23 & 0.81 & -5.23 & 6.08 & 6.76 & 45.76 & -3.12 & 10.12 \\
\hline 24 & -7.18 & 2.64 & 3.08 & 3.76 & 14.17 & -31.82 & 35.28 \\
\hline
\end{tabular}


Table 3 Covariance matrix for two stocks

\begin{tabular}{lll}
\hline Stock & $A$ & $B$ \\
\hline$A$ & $\operatorname{Cov}(A, A)$ & $\operatorname{Cov}(B, A)$ \\
$B$ & $\operatorname{Cov}(A, B)$ & $\operatorname{Cov}(B, B)$ \\
\hline
\end{tabular}

according to stock price fluctuations and is usually attributed to investor confidence level, holding period, prevailing inflation level in the economy as well as trends in a business cycle. Table 3 shows the covariance matrix for both stocks used for the calculating the expected rate of return for a given risk-free rate and equity risk premium. Since the present study involves only two stocks, the total number of covariance combinations that can be achieved between them is four and thus simpler to evaluate. However, in practice the covariance process becomes complex task when the portfolio contains large number of stocks.

The expected or required rate of return from a stock can be expressed using Eq. (4)

$$
R_{\mathrm{s}}=R_{\mathrm{f}}+\beta\left(R_{\mathrm{m}}-R_{\mathrm{f}}\right)
$$

The term $R_{\mathrm{m}}-R_{\mathrm{f}}$ indicates the equity market risk premium for a stock, $R_{\mathrm{s}}$ is expected return on stock, $R_{\mathrm{f}}$ is the risk-free rate. Conversely, the market return from a stock can be estimated by rearranging Eq. (4) and given by Eq. (5.1)

$$
R_{\mathrm{m}}=R_{\mathrm{f}}+\frac{\left(R_{\mathrm{s}}-R_{\mathrm{f}}\right)}{\beta}
$$

On the other hand, the returns from portfolio of stocks can be estimated using the weights assigned for individual stocks and their corresponding returns in portfolio. Mathematically, it can be written in the form given by Eq. (5.2)

$$
R_{\mathrm{p}}=\sum_{i=1}^{n} w_{i} \cdot R_{i}
$$

where $w_{i}$ is the weight assigned to individual stock, $R_{i}$ is required rate of return from stock. The beta for individual stocks $A$ and $B$ can be expressed using Eqs. (6) and (7)

$$
\begin{aligned}
& \beta_{A}=\frac{\operatorname{Cov}\left(A_{R}, M_{R}\right)}{\sigma_{M}^{2}} \\
& \beta_{B}=\frac{\operatorname{Cov}\left(B_{R}, M_{R}\right)}{\sigma_{M}^{2}}
\end{aligned}
$$

The cross-covariance returns are relative values and expressed as the returns from stock $A$ and stock $B$ with respect to their market return values and given by Eq. (8) and Eq. (9), respectively:

$$
\begin{aligned}
& \operatorname{Cov}\left(A_{R}, M_{R}\right)=\sum \frac{\left(A_{R}-A_{R, \mathrm{avg}}\right) \cdot\left(M_{R}-M_{R, \mathrm{avg}}\right)}{(n-1)} \\
& \operatorname{Cov}\left(B_{R}, M_{R}\right)=\sum \frac{\left(B_{R}-B_{R, \mathrm{avg}}\right) \cdot\left(M_{R}-M_{R, \mathrm{avg}}\right)}{(n-1)}
\end{aligned}
$$

Thus, a covariance for individual stocks $A$ and $B$ can be expressed by Eq. (10) to Eq. (14)

$$
\begin{aligned}
& \operatorname{Cov}(A, A)=\sum \frac{\left(A_{R}-A_{R, \mathrm{avg}}\right) \cdot\left(A_{R}-A_{R, \mathrm{avg}}\right)}{(n-1)} \\
& \operatorname{Cov}(B, A)=\sum \frac{\left(B_{R}-B_{R, \mathrm{avg}}\right) \cdot\left(A_{R}-A_{R, \mathrm{avg}}\right)}{(n-1)} \\
& \operatorname{Cov}(A, B)=\sum \frac{\left(A_{R}-A_{R, \mathrm{avg}}\right) \cdot\left(B_{R}-B_{R, \mathrm{avg}}\right)}{(n-1)} \\
& \operatorname{Cov}(B, B)=\sum \frac{\left(B_{R}-B_{R, \mathrm{avg}}\right) \cdot\left(B_{R}-B_{R, \mathrm{avg}}\right)}{(n-1)} \\
& \operatorname{Cov}\left(M_{R}, M_{R}\right)=\sum \frac{\left(M_{R}-M_{R, \mathrm{avg}}\right)^{2}}{(n-1)}
\end{aligned}
$$

The weights assigned for stock $A$ and stock $B$ can be assumed to be equal for simplicity consideration which implies, $w_{A}=0.5$ and $w_{B}=0.5$. However, it may be changed by fund managers according to portfolio size and preferential return expected from investors. The correlation coefficient is found to be 0.89 shown as an example using standard deviation of stock $A$ and stock $B$ and given by Eq. (15)

$$
\rho_{A, B}=\frac{\sigma_{A, B}}{\sigma_{A} \cdot \sigma_{B}}
$$

The resultant standard deviation for the portfolio is then calculated using weighted values of standard deviation measured for stock $A$ and stock $B$ along with correlation coefficient $\rho_{A, B}$ obtained from Eq. (15) and given by Eq. (16)

$$
\sigma_{R}^{2}=\left(w_{A} \cdot \sigma_{A}\right)^{2}+\left(w_{B} \cdot \sigma_{B}\right)^{2}+2 \cdot w_{A} \cdot w_{B} \cdot \sigma_{A, B} \cdot \rho_{A, B}
$$

In practice, however, the total risk for a stock or portfolio of stocks is dependent on unsystematic risk as well as systematic risk. In the former case, it is associated with firm's business operations and the financial goals set over 
Table 4 Comparison of risk premium and returns for two stocks $A \& B$ trading in BSE Sensex and S\&P 500 indices

\begin{tabular}{lcc}
\hline & Stock A & Stock B \\
\hline Index: S\&P 500 & 3.7 & \\
Covariance & 3.66 & 86.21 \\
Variance & 1.01 & 97.412 \\
Beta & $3.42 \%$ & 0.885 \\
Risk premium & \\
Risk free rate & $6.62 \%$ & $5.42 \%$ \\
Return & $9.95 \%$ & $7.34 \%$ \\
Index: BSE Sensex & & $12.14 \%$ \\
Covariance & 24.25 & \\
Variance & 23.31 & 261.58 \\
Beta & 1.04 & 244.46 \\
Risk premium & \\
Risk free rate & $20.32 \%$ & 1.07 \\
Return & $5.01 \%$ & $25.32 \%$ \\
\hline
\end{tabular}

\pm represents only the equity risk premium and does not include the country risk premium (e.g., reinvestment risk and default or credit risk)

long-term horizon, while in the latter it varies with the macroeconomic factors such as prevailing interest rate and inflation rate in the economy. It can be noted that investors with single investment in well-diversified portfolio can avoid the unsystematic risk. However, systematic risk remains in all portfolios irrespective of portfolio diversification as it is sensitive to market-wide factors. Table 4 shows the expected rate of return from the stocks $A$ and $B$ of two firms for varying stock betas, equity risk premium and risk-free rates assumed for both stocks.

For the present study, data are obtained from BSE Sensex and S\&P 500 market indices for industrial, manufacturing and public utility companies. Mathematical regression methods have been applied on the data sources to estimate variance of returns from a stock relative to mean returns from portfolio and thus provide a quantitative description of risk associated with the stock [21] The benchmark of market index return is important factor in predicting the individual stock's expected rate of return and its systematic risk as measured by beta and defines the security market line according to CAPM. However, it can be said that for positive correlation as risk for a stock increases, the expected returns also rise and vice versa. This may imply that stocks are not diversified and vary as linear combination of standard deviations. On the other hand, for negative correlation, risk can be reduced by diversification of stocks in portfolio. The correlation extremes for a given portfolio can be described using the envelope encompassing all combinations of stocks to produce best possible returns. The slope of characteristic line for a given stock is measured by the stocks beta and represents the line of best fit. The propensity of stock to produce returns that deviate from the characteristic market line gives residual variance, while stock variance is the individual stock propensity to produce returns that deviate from the expected value. The interest rate risk is assumed fixed or constant in this study, and effect of inflation rate is ignored for simpler calculations. This risk pertains normally to the bonds issued to the investors by the firm in the debt capital markets. Thus, beta estimates vary not only by industry but also on the firm's capital structure ratios. Further, it must be noted that stocks with beta values greater than 1 imply aggressive stocks i.e., returns increase faster than the average market return in rising market and decrease faster in falling markets. In this regard, stock $A$ from Table 4 can be considered as slightly aggressive in both market indices. Similarly, stocks with beta values less than 1 are known as defensive for which average returns in rising and falling markets are lower relative to market return. Stock B trading in S\&P 500 index can be considered as defensive while slightly aggressive in BSE Sensex market.

Figure 14a shows correlation between the stock return and its beta trading on S\&P 500 index. When risk-free rate of return is $\sim 5.01 \%$ with the beta value greater than 0.25 , the expected returns from the stock are positive and continue to rise. The maximum expected return for the stock $A$ is $8 \%$ when the beta is 1.01 which is indicative of positive linear correlation, while for stock $B$ it is $\sim 14 \%$ with a beta of 1.2 , respectively. Similarly, from Fig. 14b, the returns from stocks $A$ and $B$ trading in BSE Sensex are seen rising with increasing values for beta. The slope of the returns for both stocks can be seen steeper compared to the returns obtained from S\&P 500 index shown in Fig. 14a.

Therefore, it can be said that stock $B$ in the portfolio produces higher returns than stock $A$ for both market conditions and thus the preferred choice for investment. Portfolio variance can thus be determined based on covariance matrix obtained for individual stocks in portfolio with respect to market returns. Every covariance element in the matrix is multiplied with the weights for associated stocks in portfolio and by adding returns from each stock to obtain the variance on portfolio $[22,23]$. The portfolio return is given by the weighted average of expected rate of return of individual stocks. The weights are usually determined based on stock price information as well as buying and selling characteristics of investors. Also, from Fig. 15a, b, it can be said that the standard deviation of the portfolio returns in both markets varies linearly for strong positive correlation and implies higher risk. For negative correlation however, the standard deviation on stocks reduced exponentially when the weights in portfolio are equally distributed. In contrast, when the 


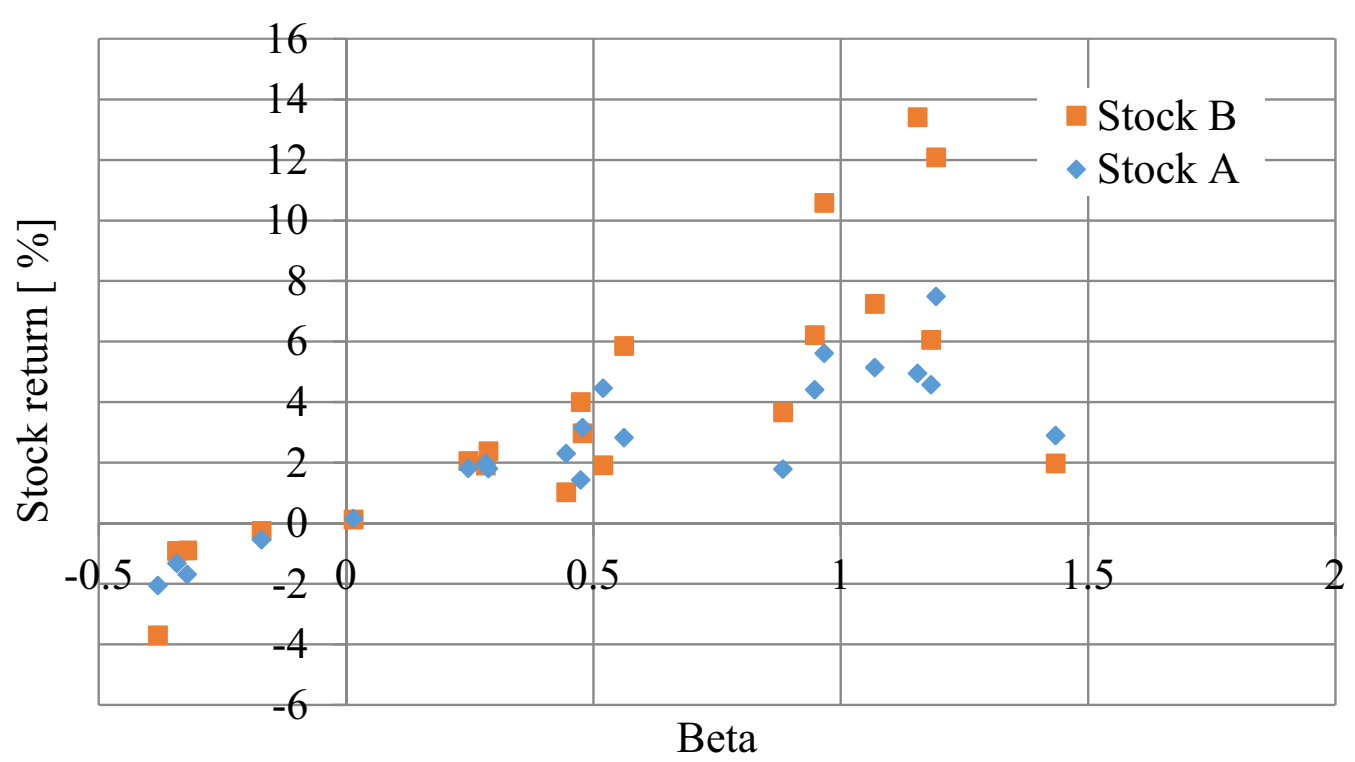

(a)

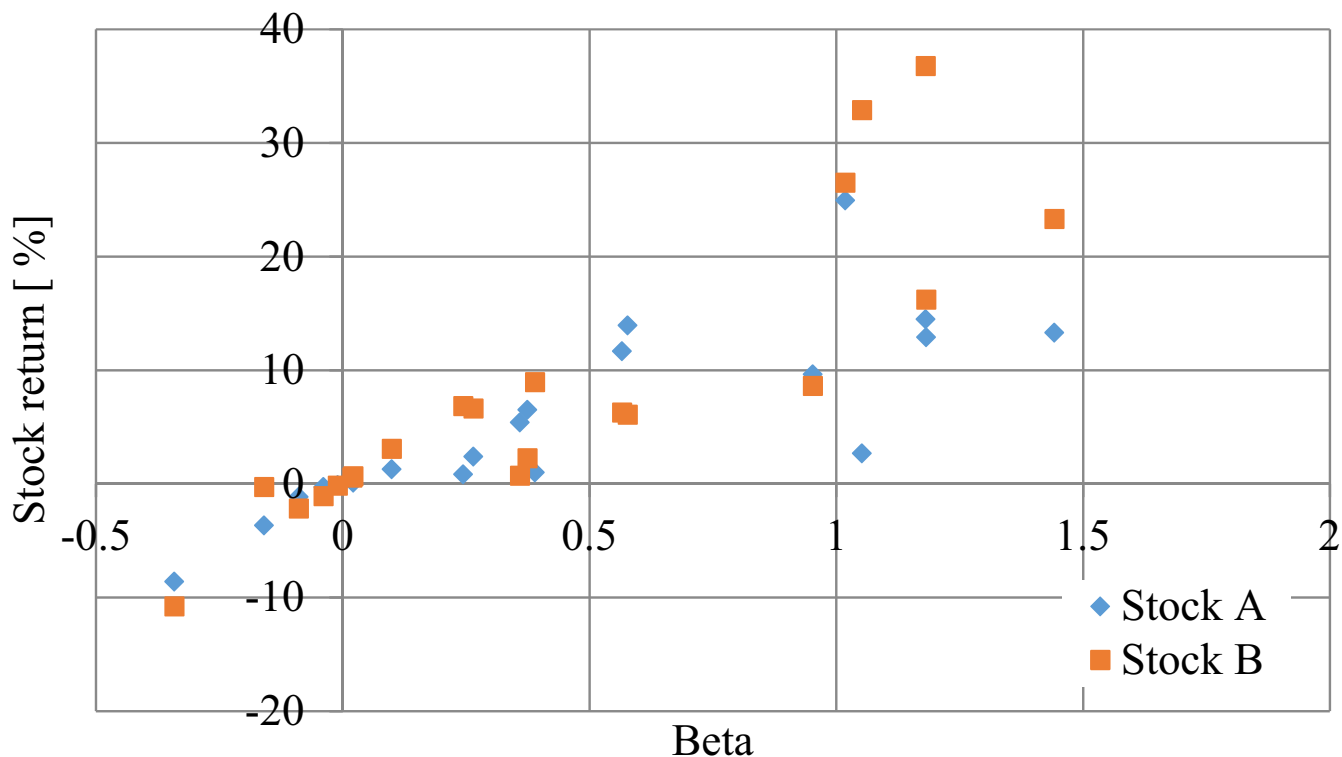

(b)

Fig. 14 Security market line of stock $A$ and stock $B$ with varying beta and market returns on a S\&P 500, b BSE Sensex

weights are not equally distributed, the standard deviation on stocks varied linearly.

The characteristic market lines for stocks $A$ and $B$ for both market indices, i.e., S\&P 500 and BSE Sensex, as shown in Fig. 16a, b. It also shows the line of best fit for the returns from individual stocks in portfolio. The slope of characteristic market line is low when the market returns are lower. It can be said that the uncertainty of the individual stock in a portfolio varies nonlinearly when market returns are positive. This implies that the relationship between firm's earnings performance and stock returns is positive when the market returns are constantly increasing, keeping other factors constant.

Further, stocks are often traded in both primary and secondary markets but at the time of first issue, they are marketed through investment bankers in primary market in conjunction with the promoters or management group; hence, the primary market becomes one of 


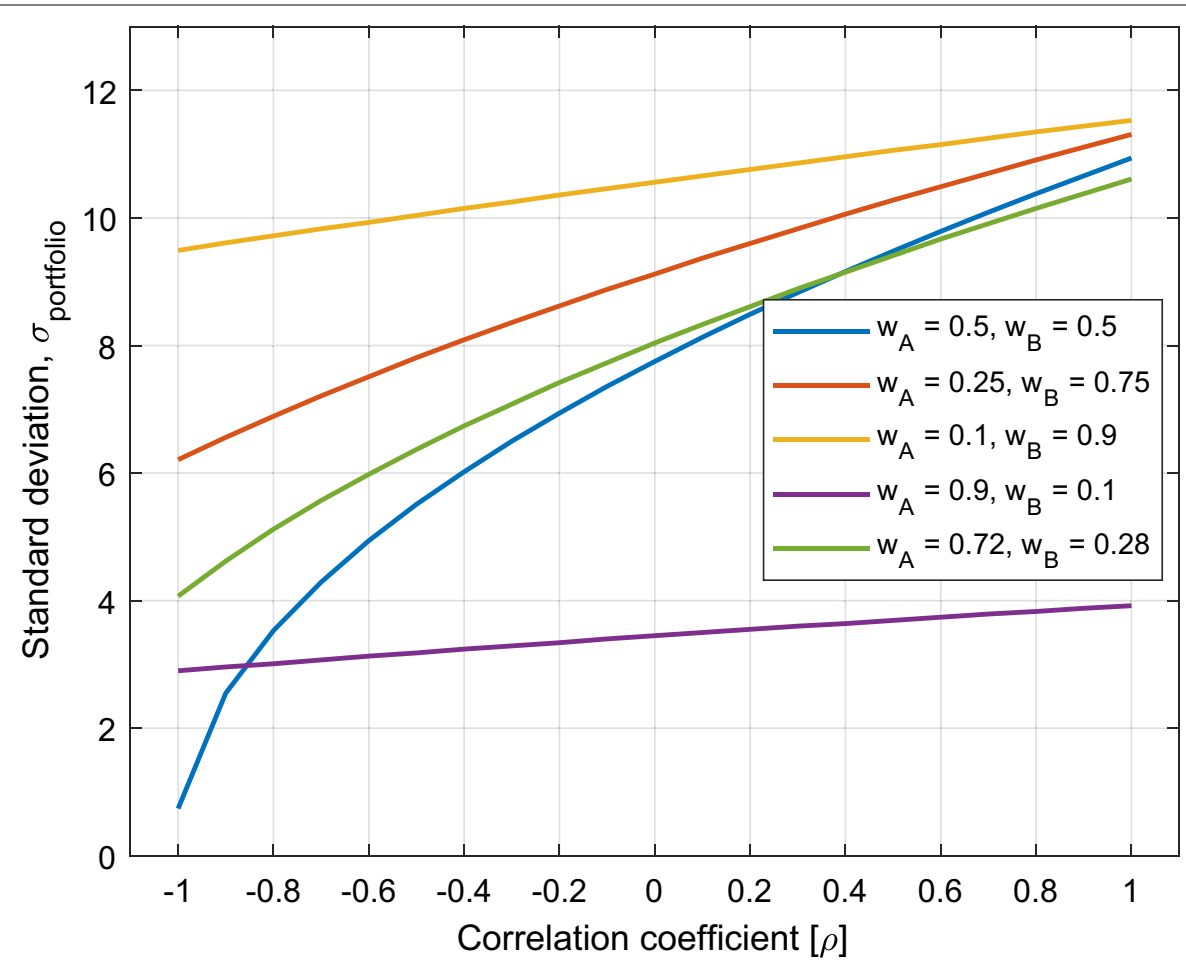

(a)

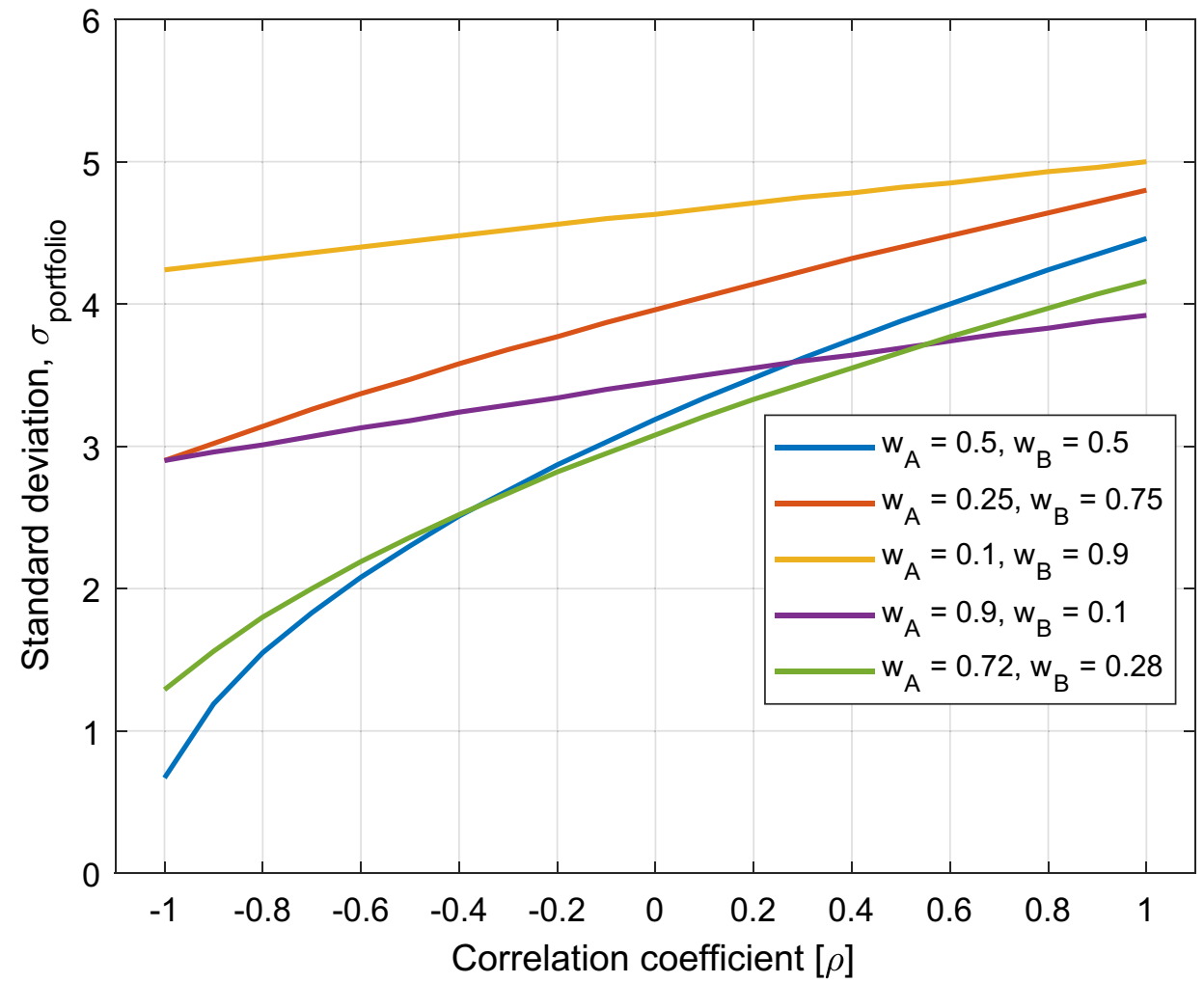

(b)

Fig. 15 Graph showing change in standard deviation with correlation coefficient for a composite portfolio a S\&P 500, b BSE Sensex 


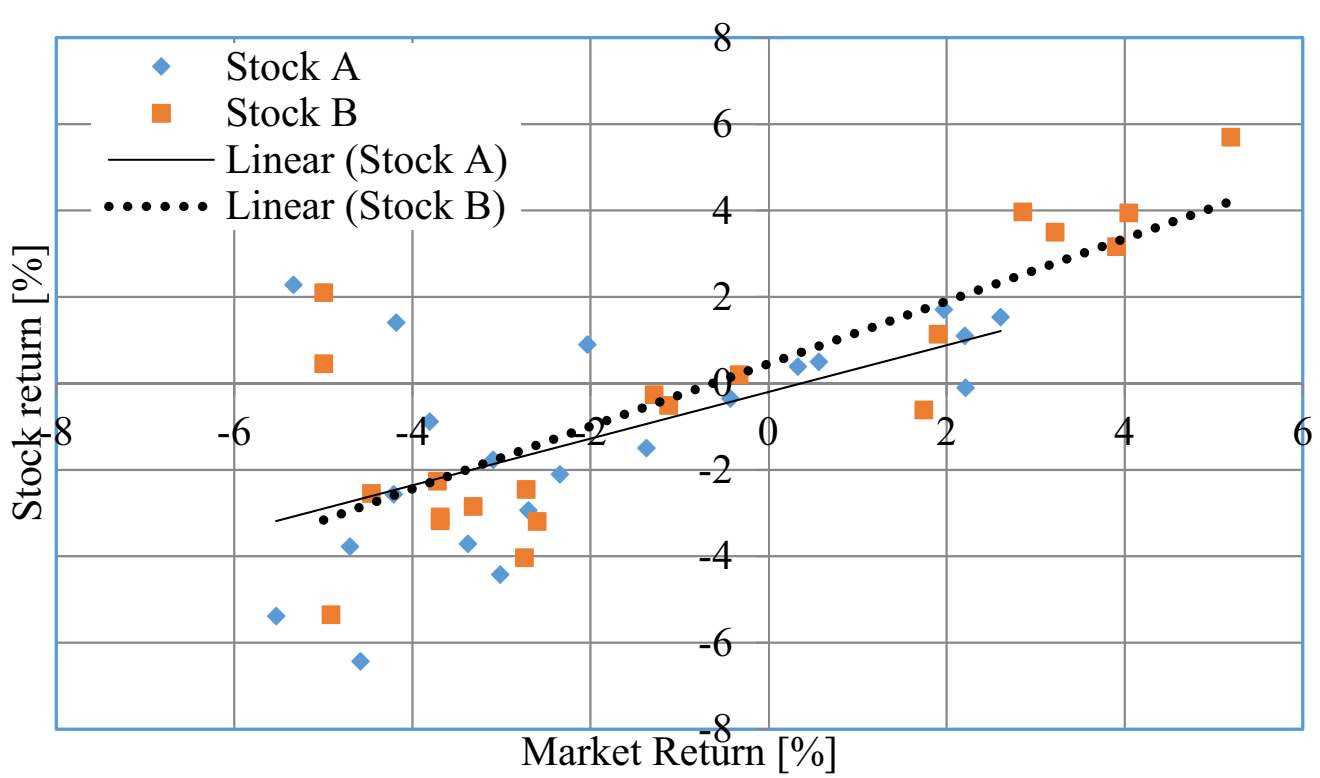

(a)

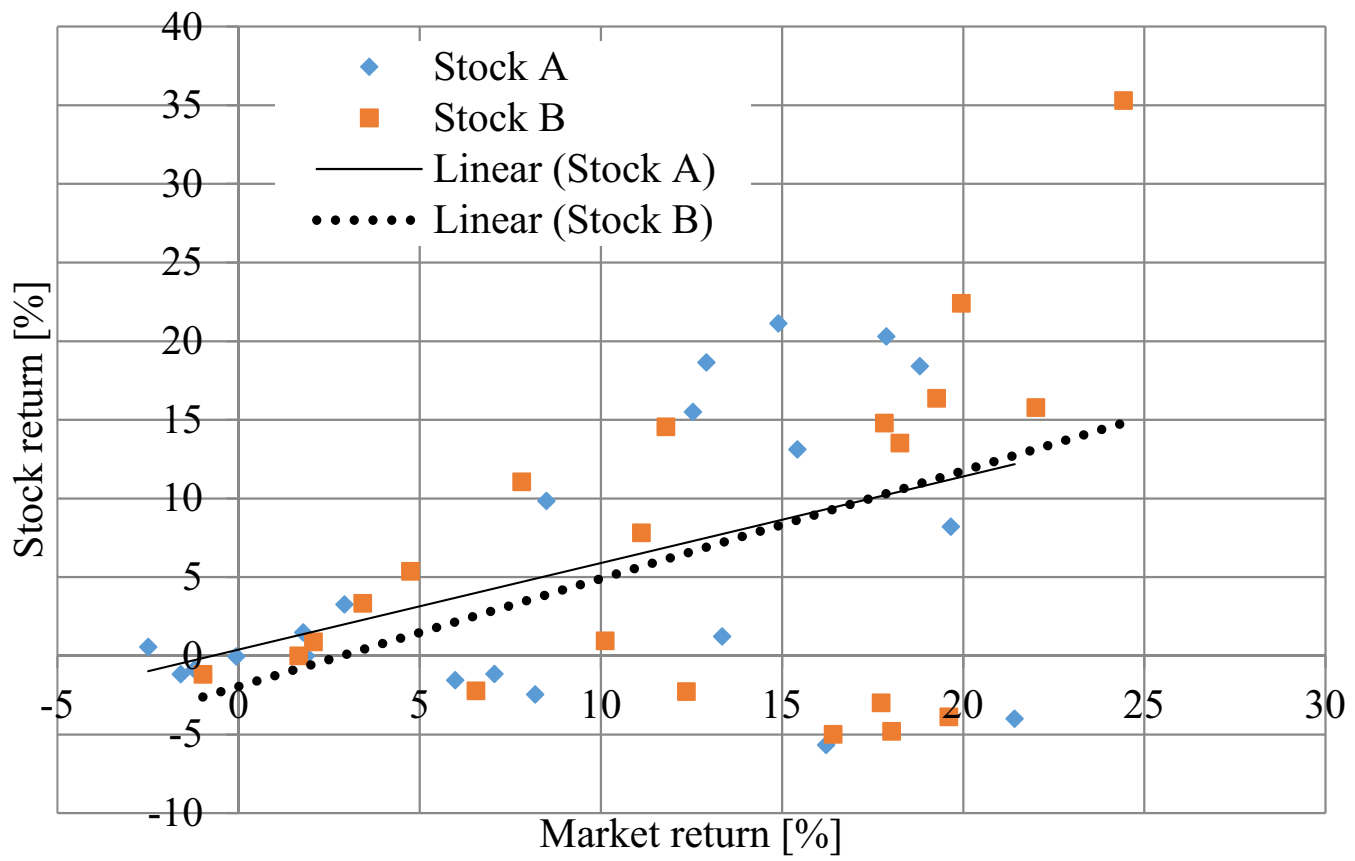

(b)

Fig. 16 Characteristic market line demonstration for stock returns A and B with respect to market return on a S\&P 500, b BSE Sensex. The dotted line and black lines show the linear fit for stock returns

the avenues where the financiers/capital providers and capital users raise capital. In addition, secondary capital market serves as the source of liquidity for investors as well. Some firms pay the dividend to shareholders, but others utilize the retained earnings as potential source of reinvestments for future growth. While dividend payments to shareholders are popular method to maximize the firm's value, such methods are adopted by technological matured firms in industry. It can be said that firms that are in growth stage may reinvest their earnings or buy back the shares and reduce share 
capital with an aim to improve the firm's stock price in long-run operations.

\section{Dividend discount model calculation}

The dividend discount model proposed by Gordon [8] expresses the relation between firm's growth rate and extent of dividend paid to shareholders which strongly influences the stock returns. Though the dividend paid to its shareholders remains entirely discretionary and limited by corporate policy, it can be said that excess or free cash flow for any firm is often associated with agency costs and to avoid such costs, firms tend to distribute them as dividend payments. This also implies that for a firm with growth opportunities, market value of share increases with dividend payout ratio as well as retention rate, thus boosting investor confidence and the shareholder returns through small increments. Also, few firms consider dividend payments as irrelevant in relation to the shareholder wealth gains as stated according to Miller-Modigliani hypothesis and therefore avoid them owing to costs associated with dividend issue in capital markets. Further, the cost of equity capital for such a firm according to the dividend growth approach by Gordon [8] states that expected returns from a stock are based on current market price as well as the growth rate of the company over the period. The total returns for a stock can be computed using the dividend payment history data for the stock and compared with the index returns and given by Eq. (17) [21]. The retained earnings for the company are taken as input for calculation of growth rate for period of 25 months. On the other hand, Walters model states that expected returns vary with firm's earnings, equity capitalization and discount rates and given by Eq. (18)

$$
K=\left[\frac{D_{o}(1+g)}{P}\right]+g
$$

where $g$ is growth rate of company, \%, $P$ is purchase price of stock, $D_{o}$ is dividends paid to shareholders; $K$ is annual or monthly expected return from the stock. $r$ is discount rate, $k_{e}$ is the cost of equity capital, $E$ is the earnings, $D$ is dividend payment per period.

$$
P=\frac{D}{k_{e}}+\frac{r(E-D)}{k_{e}^{2}}
$$

According to Walters's model, the market price of a stock is obtained using the sum of the present values of two independent sources of income. The first includes constant dividend payment stream, while the second involves the present value of capital gains that vary according to discount rate, cost of equity capital and earnings per share. It can be said that Walters model also takes account of opportunity cost of investments and that no external source of financing in the form of equity or debt can be utilized by firm.

As can be seen from Fig. 17a for stock $A$, the geometric mean returns for a stock provide more conservative outcome than the arithmetic mean. From theoretical research viewpoint, the arithmetic mean return from stock is considered more suitable; however, it does not capture the compound effects on interest income generated by total returns on index and therefore more realistic returns are expected using geometric mean. Further, Table 5 demonstrates that as the earnings of the firm increase, the growth rate continues to increase but when the earnings reduced, the growth rate also reduced. It must be noted that both earnings and growth rate of firms strongly rely on strategic growth drivers and corporate governance mechanisms, and hence, the management and supervisory board of a firm may stop dividends to the shareholders when the earnings decrease as dividends payout is associated with additional costs. The dividend payout ratios may also depend on other factors such as volatility in stock price and volume of the shares traded in secondary market [24]. On the other hand, few firms in manufacturing industry focus mainly on the growth rate as important factor to maintain leadership. Such firms may consider a buyback of shares in the open market to reinvest the capital in firm's core operations of firm as part of expansion strategy plan. Also, it must be noted effect of buyback on the firm's stock price may remain uncertain and influenced by changes to ownership structure and external economic factors, among others [25-27]. The results obtained in the present study do not take account of buybacks or repurchases of shares cases during stocks trading period. From Fig. 17b, the expected returns from stock according to Walters's model follow the firm's earnings history and project positive returns when compared to Gordon model. This difference could be due to discount rate factor considered by Walter's model being less than equal to the required rate of return for all shares issued by firm. In such cases, stock price of firm tends to be drive up the prices higher in future. So, it can be said that changes to stock price can be estimated based on changes to the earnings per share as well as the changes to $P / E$ ratio of firm. One can note that returns from Walters model have positive effect on shareholders wealth since model exhibits a quadratic relation with respect to equity rate and directly with discount rate according to Eq. (18).

\section{Total return comparison}

For evaluation of total return from the stock, the MillerModigliani assumption has been followed. Basic assumptions proposed by $\mathrm{M}-\mathrm{M}$ are argued to be unrealistic as it does not consider any transaction costs. It states that discount rates and rate of required return are identical for all stocks. In addition, it evaluates the holding period 


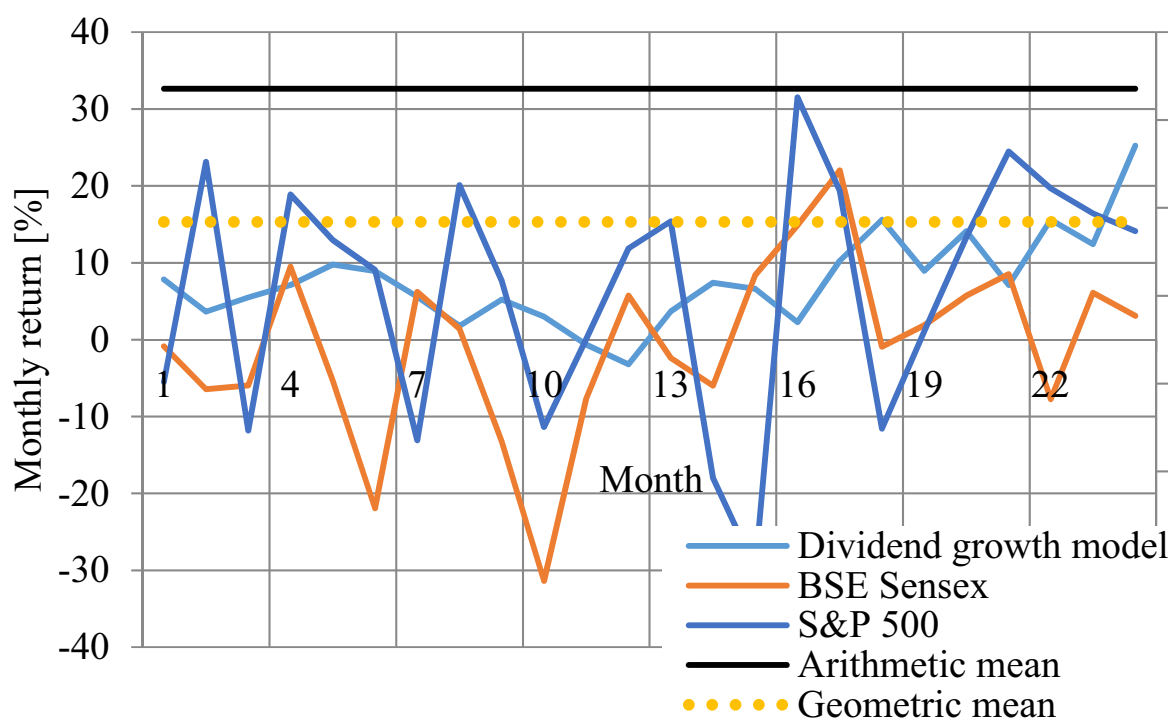

(a)

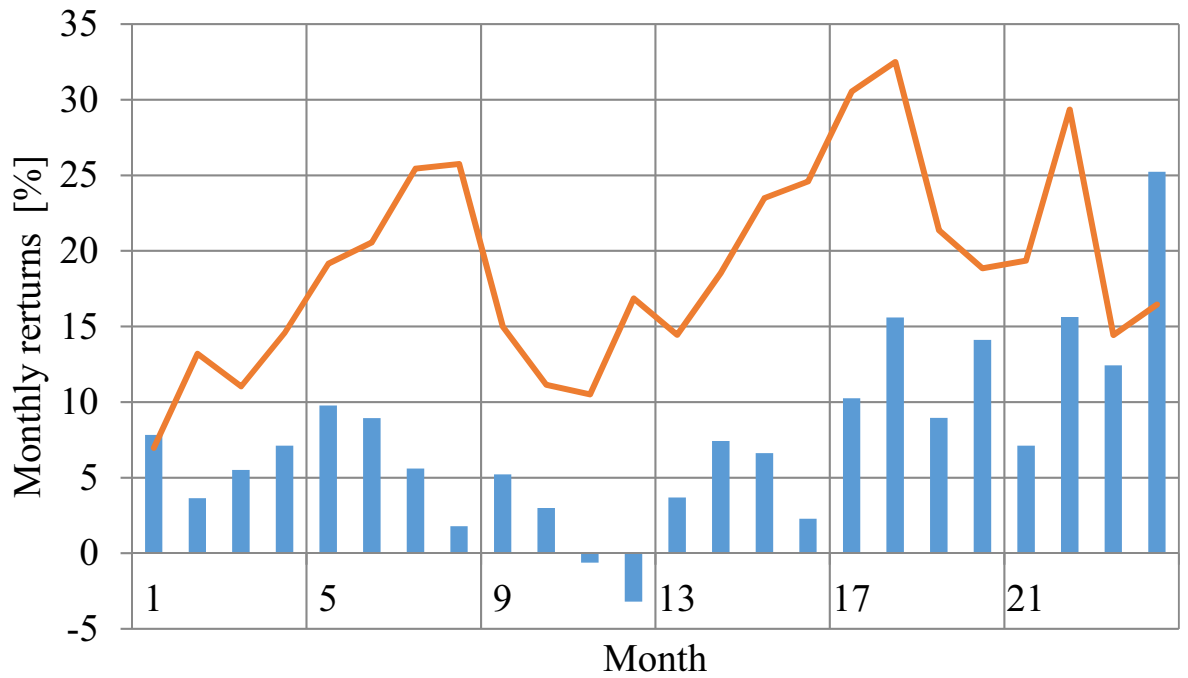

Dividend growth(Gordon) model

\section{-Walters model}

(b)

Fig. 17 a Illustration of returns from stock $A$ and dividend growth model compared with returns from BSE Sensex and S\&P 500 indices. b Comparison of returns according to Gordon growth and Walter's dividend model for a mean growth rate of $7.53 \%$ and equity capitalization rate of $30 \%$

Table 5 Growth rate, \% and dividend payout ratio based on the earnings (million)

\begin{tabular}{llllllllllll}
\hline Month & 0 & 1 & 2 & 3 & 4 & 5 & 6 & 10 & 15 & 20 & 25 \\
\hline Earnings & - & 2.1 & 7.0 & 10.8 & 11.7 & 12.6 & 10.0 & 13.4 & 7.4 & 1.9 & -3.9 \\
Growth rate & - & 7.73 & 8.59 & 9.45 & 9.74 & 9.65 & 8.80 & 5.51 & 1.74 & 5.14 & -0.63 \\
Payout ratio & - & 1.81 & 1.95 & 2.02 & 2.13 & 2.28 & 2.5 & 2.72 & 2.87 & 2.92 & 3.07 \\
\hline
\end{tabular}


return using changes to stock prices and dividend payments to investors. The rate of return for a share in any given period thus varies with dividend payment history and market price per share. Further, the total returns from a stock also vary with dividend payout ratio which implies that firm's earnings and growth rate are essential to pay periodic dividends to investors. It can be seen from Eq. (19) that total returns also depend on the opening and closing market prices of stock in index.

$$
R_{\mathrm{t}}=\frac{\left[\left(P_{\text {new }}-P_{\text {old }}\right)+D\right]}{P_{\text {old }}}
$$

where, $R_{\mathrm{t}}$ is total return of stock, $R_{\text {new }}$ is new market price of stock, $R_{\text {old }}$ is old market price of stock, $D$ is dividend paid on stock.

Monthly returns from stocks $A$ and $B$ are shown in Fig. 18 as well as the total return from stock $A$ are compared to BSE Sensex index. It indicates the returns from both the stocks follow the same trend as that of market returns, while the dividend discount model shows divergence in returns. To illustrate the impact of dividend payments on total returns from the stock, dividend payout ratio is considered. Based upon the data, it can be said that the monthly returns for stock $A$ are lower than stock $B$ when compared to market index return. Similarly, the total returns for stock $A$ are lower than individual returns due to large price fluctuations in the market despite stable dividend payout ratio.

\section{Relative valuation: price/earnings $(P / E)$ approach}

A $P / E$ ratio indicates how much investors pay more relative to net income earned by the firm per each share outstanding. Typically, share prices are affected by market sentiments as well as varying investor's goals or objectives. When there are positive trends in market sentiments, the price and firm earnings information becomes more sensitive to investors who wish to trade in long position. This also implies when the stock price is trading at premium, the investors can become wary of the volatility of returns from shares trading in secondary market. It can lead to sell off the shares by investors with an intention to make profits. On the other hand, senior management of an organization may adopt strategies to drive up the stock price with a view to increase the shareholder wealth in long-run business operations. In such cases, a $P / E$ enables financial analyst to predict stock returns in both short and long run. It can also be noted that a higher $P / E$ ratio indicates the price of stock is expensive relative to the total earnings of the firm and has implications with trading. The $P / E$ approach helps predicts the long-term stock returns on the basis of future corporate earnings using appropriate discount rate [28]. The low $P / E$ valuations show that high expected returns are possible. Highly dispersed returns in a portfolio indicate more volatility, i.e., high fluctuation in prices.

From Fig. 19, one must note that firm size is a control variable which affects the investment and financing policies framed by senior executive board [29]. More often, the financing policy of large size firms has a benefit in securing capital from banks and other investors readily compared to small size firms. Also, earnings as well as change in earnings relative to the stock price can be regarded as independent variables. However, these variables rely strongly on the firm's corporate governance mechanisms which are based on strategies intended to avoid agency costing, road maps for resource optimization, stewardship theories that reflect a sense of obligation to fulfill organizational goals and objectives by

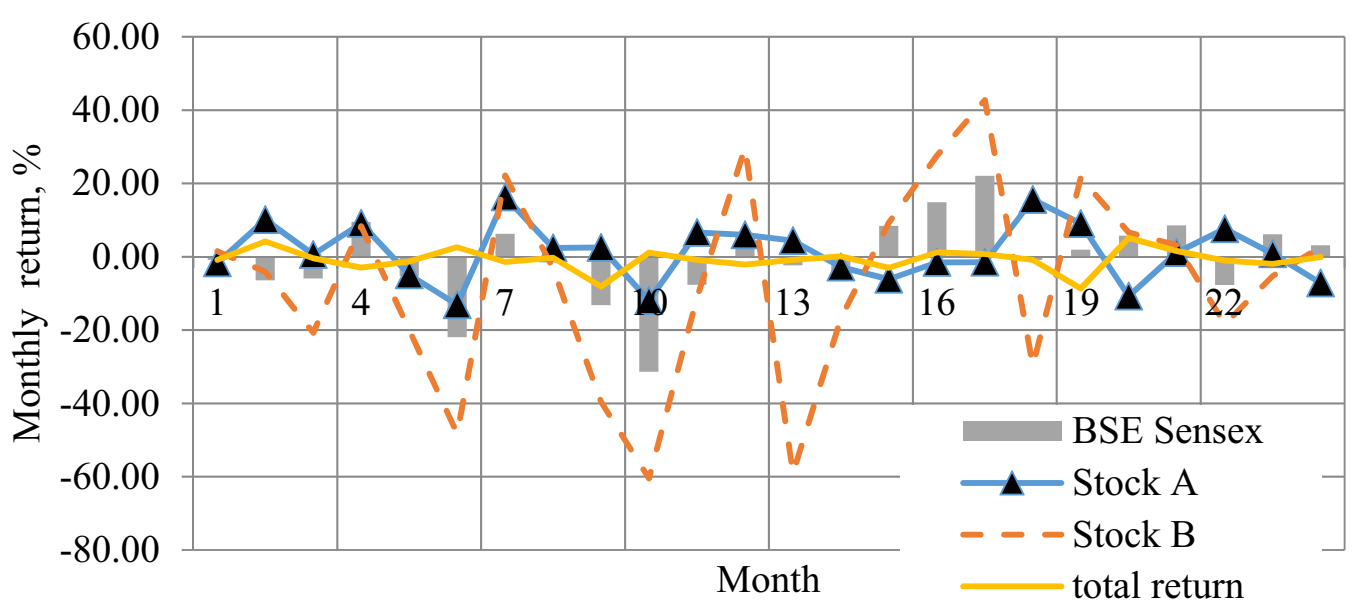

Fig. 18 Monthly returns for stocks $A$ and $B$ and total return for stock $A$ compared to return from BSE Sensex 


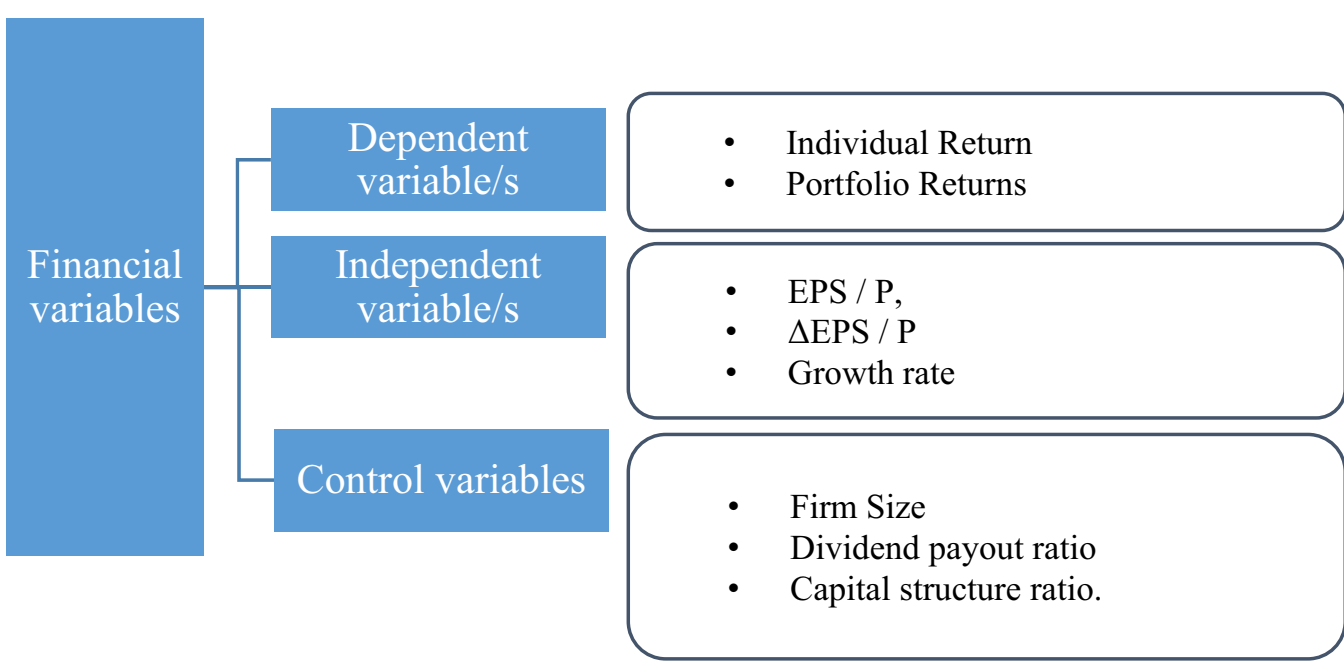

Fig. 19 Chart showing classification of finance variables in relation to the returns, firm earnings, firm size, and growth rate of firm, capital structure ratios

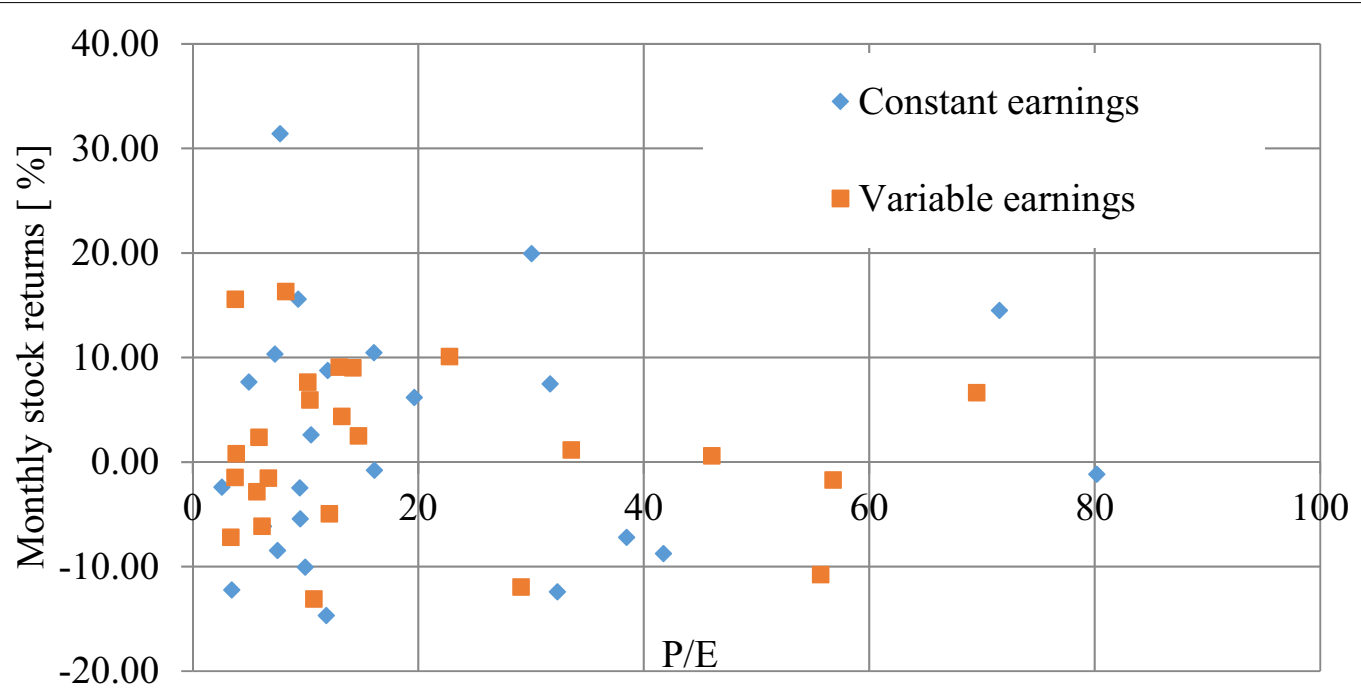

Fig. 20 Illustration of relative valuation metric $P / E$ for stock $B$ with constant and variable earnings

management with varied implications and therefore, out of scope for the present study.

Figure 20 compares the monthly stock return forstock $B$, for multiple values of $P / E$ ratios when the firm has constant and increasing earnings. When the $P / E$ ratio is low and the firm's earnings are constant, the monthly returns from the stock vary between $+10 \%$ and $-10 \%$. Also, even as the $P / E$ ratio increases, the monthly returns remain within $\pm 10 \%$ range. Under the assumption when the firm's earnings are not constant, the monthly returns vary by $\pm 20 \%$ for moderate values of $P / E$ ratios, but at low values of $P / E$, returns from stock were found increasing with higher earnings than for firm with constant earnings. It can be said that firms which tend to have higher gross margins may affect the earnings positively and hence the two cases represent functionally good examples in which price and earnings variables affect returns from a stock. 


\section{Conclusions and future work}

- In this paper, influence of debt-to-equity capital structure ratio on project investment returns is demonstrated using absolute valuation methods. The weighted average cost of capital strongly influences the internal rate of return for projects and tend to predict the biases in cash flow estimates. Cost of capital provides critical information to financial managers and enables them to take financing and investment decisions for achieving better returns when the project has more than one internal rate of return. The net present values were found to be sensitive to changes to debt-to-equity capital structure ratio.

- Risk and return analysis for a portfolio of two stocks traded in BSE and S\&P indices was studied using capital asset pricing method. The results showed standard deviation of stock returns from a portfolio varied linearly when there is positive correlation between both stocks but exhibited a nonlinear behavior when the correlation is negative.

- Basic capital asset pricing model assumes that individual stock returns vary linearly with beta. The model does not predict complex nonlinear patterns of stock prices and returns well when macroeconomic factors are considered. More realistic methods such as arbitrage pricing theory which considers all macroeconomic factors can be used for assessing individual stock/portfolio returns.

- The earnings based $(P / E)$ method have shown that the returns from a given stock depend on firm's earnings data as well as market price. The individual returns for stocks in a portfolio followed the index trend which indicates a positive covariance between stock returns and market returns. The geometric mean returns for a stock are more realistic compared to arithmetic mean returns and agree well with index returns.

- As part of future work, a probabilistic breakeven analysis can be implemented to include the variances in the composite cash flow patterns from assets over its useful economic life. The variances in the market value of assets in time horizon could be analyzed using differential maintenance replacement policy. Advanced methods such as Monte Carlo simulation can be applied for predicting the uncertainty in the cash flows generated for assets whose replacement value far exceeds the costs that are incurred during its operation and maintenance life.

\section{Acknowledgements}

Authors would like to thank all those who helped to improve the overall quality of manuscript.

\section{Authors' contribution}

First author (VBN) has contributed to drafting, formulation, editing of the methods in manuscript. Second author (SSPR) has done review of methods presented, illustrations, calculations and conceptual layout of the article.

\section{Funding}

Authors did not receive any funding for this work.

\section{Availability of data and material}

Data and material will be made available upon request.

\section{Competing interests}

Authors declare no conflict of interest for the present study.

\section{Author details}

${ }^{1}$ ICFAI University, Ranka Road, Lower Sichey Link Rd, Gangtok, Sikkim 737101, India. ${ }^{2}$ Faculty of Management, GITAM Institute of Management, GITAM Deemed to be University, Gandhinagar, Rushikonda, Visakhapatnam, Andhra Pradesh 530 045, India.

Received: 3 November 2020 Accepted: 18 February 2021

Published: 17 March 2021

\section{References}

1. Sherdan T, Martin J, Ravi Anshuman V (2009) Valuation, analysing global investment opportunities. Pearson Education, London

2. Markowitz HM (2005) Market efficiency: a theoretical distribution and so what? Financ Anal J

3. Sharpe WF (1964) Capital asset prices: a theory of market equilibrium under conditions of risk. J Finance 19(3):425-442. https://doi. org/10.2307/2977928

4. Lintner J (1965) The valuation of risk assets and the selection of risky investments in stock portfolios and capital budgets. Rev Econ Stat 47(1):13-37. https://doi.org/10.2307/1924119

5. Black F, Jensen MC, Scholes M (1972) The capital asset pricing model: some empirical tests. Studies in the theory of capital markets. Praeger New York, pp 79-121

6. Fama FE, French RK (1989) Business conditions and expected returns on stocks and bonds. J Financ Econ 25:23-49. https://doi.org/10.1016/0304405X(89)90095-0

7. William E, Pradosh S (2012) Disentangling beta and value premium using macroeconomic risk factors. Bus Econ 47:104-118. https://doi. org/10.1057/be.2012.6

8. Gordon MJ (1959) Dividends, earnings and stock prices. Rev Econ Stat 41(2):99-105. https://doi.org/10.2307/1927792.jstor1927792

9. Gottwald R (2017) The use of the dividend discount model to measure stock price volatility. J Interdiscip Res 2:24-26

10. Modigliani F, Miller MM (1958) The cost of capital, corporation finance and the theory of investment. Am Econ Rev 48(3):261-297

11. Miller MM, Modigliani Franco (1961) Dividend policy, growth and the valuation of shares. J Bus 34(4):411-433. https://doi.org/10.1086/294442

12. Panda AK, Nanda S (2018) Working Capital Financing and Corporate, Profitability of Indian Manufacturing Firms. Management Decison 56, No 2, pp 441-457, DOI 10.1108/MD-07-2017-0698

13. Van Horne JC, Dhamija S (2012) Financial management and policy, 12th edn. Pearson Education, New Delhi

14. Abdillah AN, Ikhsan S, Mutia I (2018) Factors affecting capital structure of Go Public Manufacturing companies in BEl (Indonesia Stock Exchange). Int J Account Res 6(1):1-4. https://doi.org/10.2991/ebic-17.2018.33

15. Vacek E, Spacek M, Fotr J, Kracik L (2018) Project portfolio optimization as part of strategy implementation process in small and medium sized enterprises: a methodology of the selection of projects with the aim to balance strategy, Risk and performance. Econ Manag 21(3):107-122. https://doi.org/10.15240/tul/001/2018-3-007

16. D'Amico G, De Blasis R (2019) Multivariate Markov chain stock model. Scand Actuar J 4:272-291. https://doi.org/10.1080/03461238.2019.16612 80

17. Nageshwara RM, Prasada RSS (2017) The volatility measure significance in stock valuation. Indian Inst Finance 31(2):491-508 
18. Riggs JL, David DB, Sabah UR (2000) Engineering economics, 4th ed

19. Chandra P (2010). Projects, planning, analysis, selection, financing, implementation and review-CFM-MHE professional series in finance, 8th edn

20. Juan GM, Cuneo Gonzalo Rulz (2020) Capital structure and performance in Latin American companies. J Econ Res 33(1):2171-2188. https://doi. org/10.1080/1331677x.2019.1697720

21. Fischer DE, Jordan R (2012) Security analysis and portfolio management, 6th edn. Pearson Education, London

22. Haughen R (2009) Modern investment theory, 5th edn. Eastern Economy Edition, New Delhi

23. Fahd A (2020) An empirical study of the earnings-returns association an evidence from China A-share market. Future Bus J. https://doi. org/10.1186/s43093-020-0010-8

24. Phung TMT, Tho Nguyen $H$, Tuan Nguyen M (2017) The role of financial ratios in the variance of stock trading volume in emerging stock markets. J Asia-Pac Bus 18(3):180-191. https://doi.org/10.1080/10599 231.2017.1346408
25. Chandrapala P (2011) The relationship between trading volume and stock returns. J Compet 3(3):41-69

26. Mishra A (2005) An empirical analysis of share buybacks in India. ICFAI J Appl Finance 11(5):5-24

27. Monika G (2016) Share buyback and firm's performance: a study of selected Indian companies. Int J Trends Res Dev 3(4):338-344

28. Joseph D, Aliaga Diaz R, Charles JT (2012). Forecasting stock returns: what signals matter and what do they say now?

29. Hashmi DS, Saqib Gulzar, Zeshan Ghafoor, Iram Naz (2020) Sensitivity of firm size measures to practices of corporate finance: evidence from BRICS. Future Bus J. https://doi.org/10.1186/s43093-020-00015-y

\section{Publisher's Note}

Springer Nature remains neutral with regard to jurisdictional claims in published maps and institutional affiliations.

\section{Submit your manuscript to a SpringerOpen ${ }^{\circ}$ journal and benefit from:}

- Convenient online submission

- Rigorous peer review

- Open access: articles freely available online

- High visibility within the field

- Retaining the copyright to your article

Submit your next manuscript at springeropen.com 